\title{
UNDERSTANDING EXPENDITURE PATTERNS IN RETIREMENT
}

\author{
Barbara A. Butrica, Joshua H. Goldwyn, and Richard W. Johnson*
}

CRR WP 2005-03

Released: January 2005

Draft Submitted: December 2004

\author{
Center for Retirement Research at Boston College \\ 550 Fulton Hall \\ 140 Commonwealth Ave. \\ Chestnut Hill, MA 02467 \\ Tel: 617-552-1762 Fax: 617-552-1750 \\ http://www.bc.edu/crr
}

\begin{abstract}
*Barbara A. Butrica and Richard W. Johnson are both Senior Research Associates at the Urban Institute. Joshua H. Goldwyn was a Research Assistant at The Urban Institute. The research reported herein was performed pursuant to a grant from the U.S. Social Security Administration (SSA) to the Center for Retirement Research at Boston College (CRR). The opinions and conclusions are solely those of the authors and should not be construed as representing the opinions or policy of SSA or any agency of the Federal Government or of the CRR, or the Urban Institute, its board, or its sponsors. The authors thank Adeel Saleem for estimating tax liabilities.
\end{abstract}

(C) 2005, by Barbara A. Butrica, Joshua H. Goldwyn, and Richard W. Johnson. All rights reserved. Short sections of text, not to exceed two paragraphs, may be quoted without explicit permission provided that full credit, including (C) notice, is given to the source. 


\section{About the Center for Retirement Research}

The Center for Retirement Research at Boston College, part of a consortium that includes a parallel centers at the University of Michigan and the National Bureau of Economic Research, was established in 1998 through a grant from the Social Security Administration. The goals of the Center are to promote research on retirement issues, to transmit new findings to the policy community and the public, to help train new scholars, and to broaden access to valuable data sources. Through these initiatives, the Center hopes to forge a strong link between the academic and policy communities around an issue of critical importance to the nation's future.

\section{Center for Retirement Research at Boston College \\ 550 Fulton Hall \\ 140 Commonwealth Ave. \\ Chestnut Hill, MA 02467 \\ phone: 617-552-1762 fax: 617-552-1750 \\ e-mail: crr@bc.edu \\ http://www.bc.edu/crr}

\section{Affiliated Institutions:}

American Enterprise Institute

The Brookings Institution

Center for Strategic and International Studies

Massachusetts Institute of Technology

Syracuse University

Urban Institute 


\title{
Understanding Expenditure Patterns in Retirement
}

\begin{abstract}
Understanding the consumption needs of retirees is critical to assessing the adequacy of retirement income and the possible impact of Social Security reform on the well-being of older Americans. This study uses data from the Health and Retirement Study, including a recent supplemental expenditure survey, to analyze spending patterns and consumption needs for adults ages 65 and older. Results indicate that typical older married adults spend 84 percent of after-tax household income, and nonmarried adults spend 92 percent of after-tax income. Even at older ages individuals devote a larger share of their expenditures and income to housing than any other category of goods and services, including health care. Fully 8 percent of married adults report after-tax incomes that fall short of our estimated basic-needs threshold, consisting of housing, health care, food, and clothing. By comparison, only 3 percent of married adults have incomes below the official poverty level.
\end{abstract}




\section{INTRODUCTION}

Understanding expenditure patterns in later life is critical to assessing the retirement security of older Americans. Although previous studies have examined the determinants of retirement income and wealth and projected the level of resources that will likely be available to future cohorts of retirees, relatively little is known about consumption needs at older ages and how they vary across different subgroups of the population. Better information about how much income older Americans require to live comfortably in retirement is necessary before analysts can determine how well Social Security, employer-sponsored pensions, post-retirement earnings, and private savings meet the needs of the elderly population and before they can assess the possible impact of potential Social Security reforms on economic well-being.

Popular financial advice suggests that households should strive to replace between 65 and 85 percent of pre-retirement income in retirement (Uccello 2001), but there appears to be little scientific basis for this estimate. Retirees have lower consumption needs than workers because they do not incur work-related expenses. Housing costs tend to decline at older ages once homeowners pay off their mortgages. In addition, older adults no longer need to save for retirement, and they typically pay lower taxes than younger people. On the other hand, health care costs tend to rise at older ages, and many elderly people who lack private health insurance to supplement Medicare benefits face catastrophic medical expenses (Crystal et al. 2000; Goldman and Zissimopoulos 2003). The official federal poverty level establishes an absolute lower bound for consumption needs, but it is based on surveys that are now about a half-century old, and most experts do not consider the estimates to be reliable (Citro and Michael 1995). In order to develop an accurate portrait of the well-being of older Americans, it is critical that analysts understand how aged people spend their resources. For example, a very different picture emerges if older households spend much of their resources on health care than if they devote their money to expensive vacations.

This analysis represents a first step in understanding consumption needs in later life. We examine the overall level, distribution, and composition of expenditures, and measure how expenditures vary by key individual and household characteristics, including age, race, marital status, health status, and income. We also analyze the relationship between spending and 
household income. Finally, we establish a minimum threshold for how much income elderly people need to live comfortably in retirement and estimate the share of the older population that is unable to satisfy these consumption needs.

\section{BACKGROUND}

In order to paint a complete and accurate picture of economic well-being in retirement, it is important to evaluate economic resources in relation to consumption needs. The official poverty rate is designed to measure the share of the population with insufficient income to meet basic consumption needs. The U.S. Census Bureau sets the official poverty thresholds, which vary by family size and age and change each year with the change in the price level, as measured by the Consumer Price Index (CPI). The share of the elderly population living in poverty has declined dramatically over the last half of the twentieth century. In 1959, more than one in three adults ages 65 and older received incomes below the poverty level; in 2003, only one in ten lived in poverty (U.S. Census Bureau 2004).

However, important problems plague the official poverty thresholds. They were constructed decades ago using data on food expenditure patterns that are now more than 40 years old, under the assumption that food expenditures accounted for one-third of total consumption needs. Given the tremendous technological changes that have occurred over the past 40 years, and changes in the delivery of health care, it is unlikely that these thresholds reflect the consumption needs of today's older population.

Up-to-date information on household expenditures is critical, because spending patterns at older ages appear to be changing. Out-of-pocket health care costs among older adults have been rising, in response to increases in health insurance premiums, growth in Medicare costsharing, declines in retiree health insurance coverage, and growth in prescription drug costs, which are not currently covered by Medicare. (Drug benefits will be added to Medicare in 2006, but beneficiaries will face substantial cost sharing requirements.) Tax burdens have also been increasing for older people. Since 1993 high-income people have had to pay federal income taxes on their Social Security benefits, but the threshold determining the taxability of benefits is 
not indexed to the growth in prices or wages. As a result, the share of benefits subject to tax rises each year. Moreover, the growing popularity of defined contribution pension plans, hybrid pension plans (including cash balance plans), and Individual Retirement Accounts, all of which generally provide benefits in the form of lump sum payments instead of annuities, is likely to affect spending patterns at older ages, because people who do not annuitize their wealth may limit their spending to reduce the risk of depleting their assets before they die.

In addition to traditional retirement income and financial assets, older adults can turn to other resources to finance their consumption needs. One possibility is housing equity, the most important asset for most Americans. Most older people prefer to remain in their homes, and are reluctant to move even when they could increase their standard of living by selling their homes. In principle, reverse mortgages solve this dilemma by allowing homeowners to borrow against the equity in their homes. To date, however, very few elderly people have taken advantage of these financial instruments.

\section{Previous Literature}

A number of studies have attempted to measure the adequacy of retirement resources on the basis of income. Many of them suggest that most current retirees are doing well (Gustman and Steinmeier 1999; Haveman 2003), pre-retirees are accumulating enough wealth to finance a comfortable retirement (Easterlin 1990, 1993; Sabelhaus and Manchester 1995), and future retirees are likely to receive at least as much income as previous generations (Butrica and Uccello 2004; Butrica, Iams, and Smith 2003; Smith 2002). An important limitation of these studies, however, is that they rely solely on income and wealth measures to evaluate economic well-being, and ignore potential changes in future consumption needs.

Several studies have already examined spending patterns in retirement. One line of research has focused primarily on testing the life cycle consumption hypothesis and assessing whether expenditures decline at retirement (Ameriks, Caplan, and Leahy 2001; Banks, Blundell, and Tanner 1998; Bernheim, Skinner, and Weinberg 2001; Hamermesh 1984; Hurd and Rohwedder 2003; Paulin and Duly 2002). Another line of research is less concerned with how 
expenditures change before and after retirement, and more interested in understanding differences in spending within the retired population. For example, Bahizi (2003) uses data from the Consumer Expenditure Survey (CEX) to document differences in expenditure levels and budget shares for white, black, and Hispanic retirees. Another study by Paulin (2000) examines changes in spending patterns of older adults between 1984 and 1997. But none of the studies in either area of research focuses on measuring consumption needs.

Rubin and Nieswiadomy (1997) provide a comprehensive analysis of expenditure patterns of the elderly across subgroups and over time using data from the CEX for the 1970s, 1980s, and early 1990s. Unlike most other studies, the authors are particularly concerned with understanding how economically vulnerable elderly adults allocate their expenditures to necessities, such as food, housing, and health care expenditures.

Our analysis builds on their research in several ways. First, we use relatively unexplored expenditure data from a leading survey on the income and health status of older adults. Second, we use much more recent data on expenditure patterns. Third, we use information on both expenditures and income to construct minimum needs thresholds and to estimate the share of the older population that is unable to satisfy these consumption needs.

\section{DATA AND METHODOLOGY}

Our data come from the Health and Retirement Study (HRS), a longitudinal survey of older Americans conducted by the Survey Research Center at the University of Michigan for the National Institute on Aging. Since 1992, the HRS has been following several cohorts of older respondents and their spouses. In 2000, the survey interviewed a nationally representative sample of 19,579 Americans ages 53 and older and their spouses. The HRS collects detailed information on a wide range of subjects, including basic demographic information, detailed

health status, and comprehensive income and asset information. It oversamples African Americans, Hispanics, and Florida residents, but includes sample weights used to adjust the estimates so that they represent the underlying national population. 
The HRS administered a supplemental mail survey on household expenditures to a subset of respondents in 2001. This survey, the Consumption and Activities Mail Survey (CAMS), asked respondents to report household expenditures over the past 12 months on 32 different groups of goods and services designed to capture all household spending. It also asked respondents how their spending would change if their income increased by 20 percent. Data was collected for 3,813 households. We merged the 2001 CAMS with demographic and asset information from the $2000 \mathrm{HRS}$ and income information from the $2002 \mathrm{HRS}$ (which collected data on income received in 2001). In combination with the information collected from the core HRS questionnaires, CAMS provides an unusually rich source of data on household spending at older ages.

\section{Measuring Expenditures and Income}

To make the analysis of household spending patterns more manageable, we group expenditures into the following categories:

- housing, which includes mortgage payments, home/renter insurance premiums, property tax payments, rent, utility costs (electricity, water, heat, phone, and cable and internet services), spending on house/yard supplies, and home maintenance costs;

- health care, consisting of out-of-pocket payments on insurance premiums, drugs, health services, and medical supplies;

- food, which includes expenditures on groceries but not spending on dining outside of the home;

- transportation expenditures, which consist of payments for automobile finance charges, automobile insurance premiums, gasoline, and automobile maintenance (but which exclude any spending on public transit);

- entertainment, consisting of spending on dining out, vacations, tickets to events, and hobbies; 
- gifts, which include charity and other gifts; and

- $\quad$ other consumer durables, including purchases of automobiles, refrigerators, washers and dryers, dishwashers, televisions, and computers.

The analysis also relates spending to household income. We examine three different income measures: before-tax income, after-tax income, and after-tax income plus the value of annuitized assets. Before-tax household income comes directly from the HRS, which asks the financially knowledgeable respondent in each household about multiple types of income received by him or her and the spouse (if married). ${ }^{1}$ We compute after-tax household income by subtracting estimated federal tax payments, based on the Urban-Brookings Tax Policy Center's Microsimulation Model, from before-tax income. The tax model is a detailed tax calculator that captures most features of the federal individual income tax system. Inputs into the tax model include earnings, Social Security benefits, and pension benefits. Other inputs (including interest and dividends, state and local taxes, property taxes, mortgage interest, and capital gains) are imputed from Statistics of Income (SOI) data from the Internal Revenue Service according to age, filing status, and income brackets. Finally, to capture all of the financial resources available to individuals, we estimate the annuitized value of the household's financial assets and add it to after-tax household income. ${ }^{2}$ This last measure provides a broader estimate of the financial resources available to older people, under the assumption that they chose to consume their asset holdings evenly over the rest of their expected lifetimes.

Our analysis is based on per capita household expenditures and income. Considering only total household expenditures and income could be misleading, because spending and income both tend to increase with household size. Ignoring household size could particularly

\footnotetext{
${ }^{1}$ Household income includes payments from self-employment; wages and salaries; professional practices and trades; tips and bonuses; unemployment compensation; worker compensation; welfare benefits; rental income; assets, including stocks, bonds, checking accounts, and certificates of deposit; trusts; alimony support; Social Security benefits; Supplemental Security Income (SSI) benefits; veterans' benefits; Individual Retirement Account (IRA) withdrawals; pension benefits; annuities; and other income.

${ }^{2}$ Financial assets include IRA balances; stock and mutual fund values; bond funds; checking, savings, money market, and certificates of deposit account balances; and trusts, less unsecured debt. To measure income from financial assets, we calculate an actuarially fair annuity assuming an interest rate of 7 percent.
} 
distort estimated age differences in spending, because older households tend to be smaller than younger households. Although we can estimate per capita household expenditures by simply dividing spending by the number of household members, we can only approximate per capita income. The HRS collects complete information on income only for the respondent and spouse, not for other adults who might live in the household. We set per capita income equal to household income for unmarried adults and to one-half of household income for married adults. This approach assumes that the income received by any other adults living in the household equals the average per capita income of the respondent and spouse. Because this assumption may not always hold, we also measure how our basic findings change when we restrict the sample to households that do not include any other adults.

For each measure of interest, most of our tables report the mean value between the $45^{\text {th }}$ and $55^{\text {th }}$ percentiles of the distribution. This statistic approximates the median, and better describes outcomes for typical people than the mean because it is less sensitive to extreme values. It is also a better statistic than the median, because the median value gives the breakdown for a single observation, which may not be representative of people in the center of the distribution. By using 10 percent of the sample, our statistic better describes the composition of expenditures and income for typical cases. For ease of exposition, we refer to this statistic as the median throughout the text, unless otherwise noted.

\section{Measuring Needs}

Using information on expenditures, we establish minimum consumption needs for older households. We compute the median value of expenditures on housing, health care, food, and clothing, and set our basic-needs threshold equal to the sum of these values. We compute separate thresholds for married and nonmarried adults and determine the share of those whose incomes fall short. We also consider how our results would differ under alternate definitions of minimum needs. 
One way to evaluate our thresholds for minimum needs is to consider how they compare with subjective measures of well-being collected in the HRS. In each wave, the core survey asks respondents whether their retirement experience turned out to be very satisfying, moderately satisfying, or not at all satisfying. Respondents are also asked whether they have always had enough money to buy the food they need. Additionally, the CAMS survey asked respondents how they would change their spending if their income were to rise by 20 percent. Respondents can answer that they would save or invest all of it, spend or donate all of it, spend and save some, or that they are uncertain about what they would do. Those who responded that they would spend and save some were then asked to report the percentage they would spend and the percentage they would save. If they said that they would spend 50 percent or more of it, we grouped them into the spend-all-or-most category. If they said that they would save 50 percent or more of it, we grouped them into the save-all-or-most category.

We incorporate the responses from these survey questions into our analysis to assess whether our minimum- needs thresholds appear to identify economically vulnerable older adults. In general, those who report being satisfied with their retirement and who have enough money to buy food are probably meeting their consumption needs. Similarly, respondents who claim that they would save all or most of any additional income they might receive are probably able to satisfy their consumption needs with their current levels of spending (since they claim they would not increase their expenditures even if they had more resources).

\section{Sample Criteria}

Our analytic sample consists of adults ages 53 and older, although most of the analysis focuses on adults ages 65 and older. We report results at the individual level, separately for married and nonmarried adults. All expenditures and income are expressed in 2001 dollars. After dropping a few cases with missing data, our sample includes 3,636 married adults (1,894 of whom are ages 65 and older) and 1,730 nonmarried adults (1,115 of whom are ages 65 and older). 


\section{RESULTS}

We begin by examining how expenditure and income patterns differ between younger and older age groups. We then explore how older adults allocate their resources and differences by key individual and household characteristics. Next we assess retirement security. First we analyze the relationship between spending and household income. Then we establish a minimum threshold for how much income older people need to live comfortably in retirement and estimate the share of the older population that is unable to satisfy these consumption needs.

\section{Overall Expenditure Patterns}

Although the focus of our analysis is adults aged 65 and older, we briefly compare expenditure and income patterns for midlife and aged adults (see table 1). Among married adults, including those living with nonspouses, the median value of per capita household expenditures falls with age, declining from $\$ 17,409$ at ages 53 to 64 , to $\$ 15,414$ at ages 65 to 74 , to $\$ 13,678$ at ages 75 and older. Likewise, the median value of per capita before-tax income for married people declines from $\$ 30,898$ at ages 53 to 64 , to $\$ 20,023$ at ages 65 to 74 , to $\$ 15,800$ at ages 75 and older. The median level of expenditures declines by 21 percent between the youngest and oldest age groups, whereas the median value of income before taxes declines by 49 percent. The estimated decline in financial resources narrows when we account for taxes and assets. The median value of after-tax income plus annuitized assets is only 25 percent less for married adults aged 75 and older than for married adults aged 53 to 64 .

Compared with married adults, nonmarried adults tend to have higher per capita expenditures (except for the youngest age group) but lower per capita incomes. In contrast to married individuals, median expenditures among nonmarried people are slightly higher at ages 65 to 74 than at ages 53 to 64 , and then are lower at ages 75 and older. However, similar to married individuals, median income declines with each successive age group. Between the youngest and oldest age groups, expenditures decline by only 10 percent but after-tax income plus assets declines by 19 percent. 
The allocation of expenditures across spending categories changes with age. The share of total expenditures devoted to health care costs increases between the youngest and oldest age groups for both married and nonmarried adults. This increase is offset, in part, by the decline in the share of the budget for clothing and transportation. Since quite a few of the patterns differ between married and nonmarried individuals, we explore the allocation of expenditures more closely in the next section of the paper.

Before turning to that discussion, we note that while per capita expenditures reflect the spending of all members of the household, the per capita income measure is based only on receipts by the respondent and spouse (if married), and thus excludes income received by other adult household members. Sixteen percent of the married sample and 28 percent of the nonmarried sample live with individuals other than their spouses. To test the sensitivity of our findings to these differences, we also report results that exclude those living with nonspouses. When we exclude adults living with nonspouses, we find that median expenditures increase for all age groups, median income increases for most age groups, and that budget shares remain fairly constant for those ages 65 and older.

\section{Expenditure Patterns within Subgroups}

The median value of per capita household expenditures for married adults ages 65 and older stands at $\$ 14,792$ (see table 2). Housing is the largest spending category overall, followed by health care, food, transportation, entertainment and gifts, other consumer durables, and clothing. Specifically, typical married individuals devote 29 percent of their total expenditures to housing. They devote another 20 percent to health care, 13 percent to food, and 12 percent to transportation. Entertainment and gifts represent 10 percent of total expenditures. Other consumer durables, such as appliances, account for 4 percent of total spending, and clothing accounts for 2 percent. Interestingly, housing and health care alone account for close to half of total household expenditures for typical older married adults. One reason for the relatively steep housing expenditures is that the aged are increasingly likely to hold mortgages on their homes (Gist and Figueiredo 2002), which tend to raise housing costs. Indeed, our data show that 25 percent of married adults ages 65 and older are homeowners with mortgages. 
For nonmarried adults, the median value of per capita expenditures is $\$ 16,178$, higher than the level for married adults. Relative to married adults, nonmarried adults allocate larger shares of their spending to housing (39 percent), food (15 percent), and clothing (3 percent), but smaller shares to health care (16 percent), transportation (9 percent), entertainment and gifts (7 percent each), and other consumer durables (3 percent). Similar to married adults, housing and health care account for more than half of total household expenditures for typical nonmarried adults.

Given the attention paid to the burden of health care costs at older ages, it is somewhat surprising that health care is not the largest spending category among older adults. Earlier studies based on the Medicare Current Beneficiary Survey (MCBS) found that out-of-pocket health care costs consume about 20 percent of income for adults ages 65 and older, and up to one-third of income for those with limited financial resources (Caplan and Brangan 2004; Crystal et al. 2000; Gross et al. 1999). Our estimates imply lower burdens of health care spending, particularly for nonmarried adults (because, as we demonstrate later, typical older adults do not spend all of their incomes). The differences between our study and previous research appear to stem from the underreporting of income in the MCBS (Goldman and Smith 2001).

Not surprisingly, total expenditures increase with income. Married adults in the highest income quintile consume 2.5 times more than their counterparts in the bottom income quintile. The gap in expenditures between the highest and lowest income quintiles is even wider for nonmarried adults. Relative to high-income groups, low-income groups allocate larger shares of their budgets to health care and food, and smaller shares to entertainment and gifts. Rubin and Nieswiadomy (1997) found a similar relationship in CEX data between income and both health care and food expenditures. The authors also found that the share devoted to housing increased with income. However, we do not find a clear relationship between income and housing expenditures in the HRS. 
Table 3 reports per capita expenditures for married adults by personal characteristics, and table 4 reports expenditures for nonmarried adults. There is tremendous variation in spending patterns by personal characteristics, for both married and nonmarried adults. In general, household spending varies directly with socioeconomic status, reflecting differences across groups in average income levels. Groups with the highest expenses include whites, those who completed college, those in excellent and very good health, those with employer-sponsored health insurance, homeowners with mortgages, and those living in urban settings. In contrast, groups with the lowest expenses include Hispanics, high school dropouts, those in fair or poor health, Medicaid recipients, renters, and those living in rural settings. As expected, we also find that disadvantaged groups tend to devote significantly higher shares of their total expenses to essential items, such as housing, and smaller shares to nonessential items, such as entertainment and gifts. Because the patterns do not generally differ by marital status, we restrict the discussion to married adults.

Expenditure patterns differ markedly by race and ethnicity. Married whites spend $\$ 15,189$ on a per capita basis, 26 percent more than blacks $(\$ 12,024)$ and 113 percent more than Hispanics $(\$ 7,125)$. Married blacks and Hispanics allocate over 40 percent of total expenditures to housing, compared with only 27 percent for whites. Blacks also spend substantially less than whites on entertainment and other consumer durables. Hispanics, on the other hand, devote much smaller shares of their budgets to health care, food, and gifts, and larger shares to transportation. Using CEX data, Bahizi (2003) found similar differences by race. Specifically, he found that blacks spend a larger share on housing than either whites or Hispanics, and Hispanics allocate a larger percentage of their expenditures to transportation. The author also found that blacks and Hispanics allocate a larger percentage of their expenditures to food than whites. We find that nonmarried Hispanic adults devote disproportionate shares of their budgets to food, but we do not find any other race and ethnicity differences in food expenditures.

The value of median expenditures among married individuals with at least some college education is $\$ 19,211,86$ percent more than high school dropouts $(\$ 10,346)$ and 38 percent more than high school graduates $(\$ 13,967)$. Relative to those with some college education, high school dropouts and high school graduates allocate larger shares of their total expenditures to 
housing, health care, and transportation, and smaller shares to entertainment, and consumer durables.

As expected, the share of total expenditures devoted to health care is relatively large for those with health problems, and the share devoted to housing is relatively large for homeowners with mortgages and renters. Specifically, typical older married adults in excellent or very good health spend $\$ 17,134,13$ percent of which they allocate to health care expenses. In contrast, those in fair or poor health consume only $\$ 12,499$, but allocate 22 percent to health care. Additionally, typical older married adults with employer-sponsored health insurance spend $\$ 16,21014$ percent of which they dedicate to health care expenses. Those with private nongroup insurance, however, spend only $\$ 14,533$, but allocate 28 percent to health care. Finally, typical older married homeowners with mortgages consume $\$ 19,639$ and spend 39 percent on housing. Although median renters consume only $\$ 13,999$, they devote 34 percent of their expenditures to housing. However, even homeowners who have paid off their mortgages spend 28 percent of their total expenditures on housing-related expenses.

Budget shares for housing and entertainment, in particular, vary considerably by urbanicity. Median per capita expenditures are about $\$ 15,900$ for typical older married adults living in urban and suburban areas, who spend between 28 and 30 percent of their budgets on housing and between 14 and 16 percent on entertainment. In contrast, median expenditures are only $\$ 12,600$ for those living in rural areas, who spend 37 percent on housing but only 9 percent on entertainment.

\section{Distribution of Expenditures}

Table 5 examines the distribution of per capita household expenditures and the allocation of expenditures at different points in the distribution. Mean per capita expenditures for married adults increase from $\$ 6,487$ between the $5^{\text {th }}$ and $15^{\text {th }}$ percentiles of the distribution to $\$ 38,749$ between the $85^{\text {th }}$ and $90^{\text {th }}$ percentiles. Those with lower expenditures allocate relatively more to housing, food, and transportation. In contrast, those with higher expenditures allocate relatively more to entertainment, gifts, and other consumer durables. The share of expenditures dedicated 
to health care increases between the $5^{\text {th }}-15^{\text {th }}$ and $45^{\text {th }}-55^{\text {th }}$ percentiles, and then declines. Expenditures on clothing, on the other hand, are relatively constant across the distribution.

Mean per capita expenditures for nonmarried adults increase from $\$ 5,626$ between the $5^{\text {th }}$ and $15^{\text {th }}$ percentiles of the distribution to $\$ 46,746$ between the $85^{\text {th }}$ and $90^{\text {th }}$ percentiles. Similar to married adults, those with lower expenditures allocate relatively more to housing and food, and less to entertainment, gifts, and other consumer durables. However, expenditures on health care, transportation, and clothing vary inconsistently across the distribution of overall expenditures.

Finally, it is worth noting that per capita expenditures are higher for married adults than for nonmarried adults through the $20^{\text {th }}$ to $30^{\text {th }}$ percentiles, and are lower thereafter. Also, the distribution of expenditures is much more equal for married individuals than for nonmarried individuals. For example, the ratio of mean expenditures between the $85^{\text {th }}$ and $95^{\text {th }}$ percentiles to mean expenditures between the $5^{\text {th }}$ and $15^{\text {th }}$ percentiles is 6.0 for married adults and 8.3 for nonmarried adults.

\section{Housing Expenditures}

As we have already noted, even at older ages both married and nonmarried adults devote a disproportionate share of their total expenditures to housing. In this section, we further explore the reason for relatively high housing expenses in later life. Table 6 shows that for married adults utilities represent the largest housing spending category (9 percent of total expenditures), followed by property taxes (6 percent), mortgage payments and housing maintenance (5 percent each), insurance ( 2 percent), and rent ( 1 percent). We find that the share going to mortgages declines with age, whereas the shares going to utilities and maintenance increase with age. Blacks devote a disproportionate share of their total expenditures to housing because they tend to have high mortgage payments, which represent 21 percent of total expenditures for the typical black older married adult. Hispanics, who also allocate a larger than average share of their overall expenditures to housing, devote 11 percent to mortgage payments and 7 percent to rent. 
Married homeowners with mortgages, regardless of race or ethnicity, allocate 18 percent of their total expenditures to mortgage payments. In contrast, renters allocate 13 percent of their total expenditures to rent.

For nonmarried adults, utilities also represent the largest component of household spending, accounting for 13 percent of total expenditures (see table 7). Rent accounts for another 9 percent of expenditures, a much larger share than for married adults because nonmarried individuals are nearly three times more likely to rent their homes. Nonmarred adults also devote 7 percent of total spending to household maintenance, 5 percent to property tax, 3 percent to mortgage payments, and 2 percent to insurance.

\section{Health Care Expenditures}

For typical older adults, budget shares for health care expenses are second to housing costs. However, health care expenditures warrant special attention because they tend to be much more unpredictable than housing costs, especially for those without private supplemental health insurance. In this section, we break out the health care expenditures of older adults. Health insurance premiums represent the largest health care spending category ( 8 percent of total expenditures) for married individuals (see table 8). Additionally, they spend 6 percent on prescription drugs, 4 percent on health services, and 1 percent on medical supplies. This find ing is consistent with Rubin and Nieswiadomy (1997) who found that the increase in health care expenditures between the 1980s and 1990s was driven primarily by insurance premiums, followed by drugs and medical supplies, and health services.

Older married adults in poor health allocate twice as much of their overall spending to prescription drugs than those in excellent or very good health. As expected, individuals with non-group insurance spend a larger-than-average share of their overall expenditures on health insurance premiums, but they also spend a larger-than-average share on prescription drugs. These patterns are very similar for nonmarried adults (see table 9). 


\section{Expenditures Relative to Income}

In order to assess retirement security, we consider an individual's expenditures relative to his or her economic resources. Table 10 compares median expenditures, before-tax income, after-tax income, and after-tax income plus the value of annuitized assets for older married adults, by key personal characteristics. It also reports the median ratio of expenditures to income, for each measure of income. At the median, married adults consume 81 percent of their before-tax income and 84 percent of their after-tax income. If we include their annuitized financial assets in after-tax income, to better measure all of their economic resources, this share falls to only 59 percent. Not surprisingly, the ratio of expenditures to income increases with age. Typical married adults ages 65 to 74 spend 82 percent of their after-tax incomes, compared with 90 percent for those ages 75 and older.

Although expenditures are lower than average for many economically vulnerable subgroups, they tend to spend relatively large shares of their income. For example, the median value of per capita expenditures among married individuals is 26 percent higher for whites than blacks $(\$ 15,189$ vs. $\$ 12,024)$. However, the median value of per capita after-tax income is 53 percent higher for whites than blacks (\$18,513 vs. \$12,250). As a result, blacks consume larger shares of their income than whites. For whites, expenditures amount to 84 percent of after-tax income and 60 percent of after-tax income plus annuitized assets. In contrast, expenditures total 92 percent of after-tax income for blacks. Because blacks tend to hold fewer financial assets than whites, their ratio of expenditures to income only drops to 83 percent after accounting for the value of annuitized financial assets. Unlike blacks, Hispanics have much lower expenditures than whites, and thus consume a lower-than-average share of their after-tax incomes (76 percent). Like blacks, however, they are less likely than whites to have financial assets. Consequently, they consume a higher-than-average share of their after-tax income plus annuitized assets (72 percent) than whites.

Similar patterns of expenditures and income are evident by education, health status, health insurance type, housing tenure, urbanicity, expenditure level, and income level, with disadvantaged groups consuming disproportionate shares of their incomes. Because 
economically vulnerable groups tend to hold only limited financial assets, accounting for income from annuitized assets magnifies the subgroup differences. In particular, high school dropouts and high school graduates consume 69 and 62 percent of their after-tax income plus assets, respectively, whereas college graduates consume only 52 percent of their income plus assets. Similarly, those in fair or poor health consume 68 percent of their resources and those in good health spend 62 percent. However, those in excellent or very good health spend only 53 percent of their after-tax income plus assets. Although typical Medicaid recipients spend less than half as much as other older married adults, they consume virtually all of their after-tax incomes, because their incomes are so low. And because the median Medicaid recipient is in debt, he spends 110 percent of his after-tax income plus net assets.

We also find that both homeowners with mortgages and renters consume about threequarters of their after-tax income plus assets. In contrast, homeowners without mortgages spend only about half of their income. Although there are suburban and rural differences in expenditures as a share of income, these mostly disappear after accounting for annuitized financial assets.

Not surprisingly, expenditures as a share of income increase with spending and decrease with income. Married adults in the lowest expenditure quintile consume only 39 percent of their income plus assets, while those in the highest quintile spend 82 percent of their income. Individuals in the lowest income quintile consume between 99 and 107 percent of their after-tax income plus annuitized assets. In contrast, those in the highest income quintile spend between 31 and 37 percent of their income.

In most cases, expenditures consume larger shares of income for nonmarried adults than for married adults (see table 11), again because nonmarried adults tend to have higher per capita expenditures and lower per capita incomes. Median nonmarried adults ages 75 and older spend nearly all of their after-tax incomes (96 percent), while those ages 65 to 74 spend 86 percent. Like married adults, never married adults tend to have higher per capita incomes than other marital groups. As a result, they consume just over half of their income plus assets, while those who are separated, divorced, or widowed consume more than two-thirds of their resources. 


\section{Consumption Needs}

Using information on expenditures and income, we establish minimum consumption needs for older households and measure the share and characteristics of those who fall below these thresholds (see table 12). The first measure captures basic needs and includes expenditures on housing, health care, food, and clothing. For older married adults, the median value of per capita expenditures amounts to $\$ 3,823$ for housing, $\$ 1,850$ for health care, $\$ 1,560$ for food, and $\$ 250$ for clothing. Median expenditures on health care, food, and clothing are similar for nonmarried adults, whereas median housing costs are about $\$ 1,500$ higher for older nonmarried adults than for their married counterparts. Our estimate of median food expenses is very close to the cost of food under the U.S. Department of Agriculture's Thrifty Food Plan, which the federal government uses to allocate food stamps. ${ }^{3}$ We sum these values to construct a basic needs threshold, which amounts to $\$ 7,483$ for married individuals and $\$ 8,870$ for nonmarried individuals in 2001.

Although our measures of need reflect the ability of married people to live more efficiently than single people, the economies of scale in household production implied by our measures are smaller than those incorporated into the official poverty thresholds. Our estimates imply that a married individual requires 84 percent as much income to meet basic needs as a nonmarried person. By contrast, the official poverty thresholds imply that married older adults need only 63 percent as much income as nonmarried people. ${ }^{4}$ It is not surprising, then, that only 3 percent of married individuals in our sample have incomes below the poverty threshold, but 8 percent have incomes below our basic needs threshold. ${ }^{5}$ The estimate based on before-tax income comes closest to the Census Bureau's definition of resources since it ignores taxes and excludes potential income from assets. However, if we account for taxes and income from assets

\footnotetext{
${ }^{3}$ In December 2001, food costs under the USDA Thrifty Food Plan were $\$ 1,536$ per person for a two-person household with members aged 51 and older. They were \$1,691 for a one-person male household and $\$ 1,660$ for a one-person female household (U.S. Department of Agriculture, 2002).

${ }^{4}$ In 2001 , the poverty threshold was $\$ 10,715$ for married couples (or $\$ 5,358$ per person) and $\$ 8,494$ for nonmarried people (U.S. Social Security Administration 2004).

${ }^{5}$ Official U.S. Census (2004) estimates, based on the Current Population Survey (CPS), indicate that 10 percent of adults aged 65 and older were in poverty in 2001. This statistic is higher than our estimate of 7 percent because the CPS appears to underestimate income relative to the HRS (Hurd, Juster, and Smith 2003).
} 
in our definition of resources the share in need among older married adults declines to 6 percent. In contrast, the share of nonmarried individuals with incomes below the poverty threshold is very similar to the share with incomes below the basic needs threshold, because the two thresholds are quite similar.

What we include in the measure of need is somewhat subjective. One could argue that transportation is a necessity, particularly for those who do not live in urban areas. Adding transportation to the basket of necessary goods and services raises the threshold to $\$ 8,733$ for married individuals and increases the share in need to 12 percent (based on before-tax incomes). For nonmarried individuals, the threshold increases to $\$ 10,003$ and the share in need increases to 24 percent. Allowing for entertainment costs increases the threshold for married individuals by over $\$ 1,000$, to $\$ 9,833$, and increases the share in need to 16 percent. For nonmarried individuals, the threshold increases to $\$ 10,703$ and the share in need increases to 27 percent.

One way of evaluating our thresholds for minimum needs is to consider how they compare with subjective measures of well-being collected in the HRS. We incorporate into the analysis responses to survey questions about whether respondents are satisfied with retirement, whether they have enough money to buy food, and how they would change their spending if their incomes were to rise. Overall, 68 percent of adults aged 65 and older report being very satisfied with retirement, 97 percent report having enough money to spend on food, and 39 percent report that they would save all or most of any extra money they received. Only 4 percent report being dissatisfied with retirement, 3 percent report lacking sufficient money to spend on food, 17 percent report that they would spend all or most of any additional money they received, and 44 percent report being uncertain about whether they would save or spend extra income.

Regardless of the threshold we use to define minimum needs, we find that older adults who are dissatisfied with retirement, who do not have enough money to buy food, or who would spend any extra income if they had it are more likely to be in need than other people. For example, after-tax income falls short of our estimate of basic consumption needs for 29 percent of older adults who report being dissatisfied with retirement, compared with only 6 percent of those who report being very satisfied with retirement (see table 13). Similarly, 27 percent of 
those who report lacking enough money for food have insufficient financial resources to meet basic consumption needs, compared with 10 percent of those who report having enough money to buy food. Only 5 percent of older adults who say they would save all or most of any extra money they received are in need, compared with 9 percent of those who would spend all or most of it and 15 percent of those who are uncertain about what they would do.

\section{CONCLUSIONS}

Up-to-date information on the consumption needs of older Americans is crucial to policymakers as they consider reforms to the Social Security system. While benefit cuts may be necessary to achieve solvency, little is known about how they might affect standards of living for aged households. Many studies have examined the level of resources available to older people and how it is likely to change over time, but there has been remarkably little research on the amount of resources they need to live comfortably in retirement. This research fills a critical gap in the literature.

We find that housing and health care are the two largest spending categories. What is somewhat surprising is that even at older ages individuals spend more on housing than health care. However, older people appear to be increasingly likely to enter retirement with preexisting mortgages, or to refinance their homes in retirement to cover expenses. Indeed, homeowners with mortgages make up nearly a quarter of our sample. These individuals have higher-than-average expenditures and consume a higher-than-average share of their income. While health care spending accounts for smaller shares of expenditures and income than housing, these shares increase with age and poor health.

In order to assess retirement security, it is necessary to consider expenditures relative to economic resources. At the median, married adults consume between 59 and 84 percent of their household income, depending on whether income is measured before-tax or after-tax, and whether the income measure includes annuitized assets. Nonmarried adults consume a larger share of their income, ranging from 68 to 92 percent. In general, expenditures are lower than 
average for economically vulnerable groups; however, but they consume a disproportionate share of their income. Spending patterns vary less across groups than income patterns.

As policymakers consider reforms to the Social Security system, it is important to understand how much older people need to live comfortably in retirement. To this end, we construct a basic needs threshold consisting of housing, health care, food, and clothing expenditures. We find that after-tax incomes fall short of our basic needs threshold for 8 percent of married individuals in our sample, but that only 3 percent are officially considered poor. Even when we expand our definition of resources to account for potential income from assets, the share in need stands at 6 percent. In contrast, the share of nonmarried individuals with incomes below the basic needs threshold is very similar to the share with incomes below the official poverty threshold. However, when we expand our definition of minimum needs to account for other expenditures (such as transportation and entertainment costs), the gap between those in need and those in poverty increases for both married and nonmarried adults. Finally, we find that older adults who report being dissatisfied with retirement, who report lacking enough money to buy food, and who report that they would spend any extra income they might receive instead of saving it are especially likely to fall below our basic-needs threshold. This result suggests that many of these individuals are probably unable to meet their consumption needs. 


\section{REFERENCES}

Ameriks, John, Andrew Caplan, and John Leahy. 2002. "Retirement Consumption: Insights from a Survey." NBER Working Paper No. 8735. Cambridge, MA: National Bureau of Economic Research.

Bahizi, Pierre. 2003. "Retirement Expenditures for Whites, Blacks, and Persons of Hispanic Origin." Monthly Labor Review. June: 20-22.

Banks, James, Richard Blundell, and Sarah Tanner. 1998. "Is There a Retirement-Savings Puzzle?" American Economics Review 88(4): 769-788.

Bernheim, B. Douglas, Jonathan Skinner, and Steven Weinberg. 2001. "What Accounts for the Variation in Retirement Wealth Among U.S. Households?" American Economics Review 91(4): 832-857.

Butrica, Barbara A. and Cori E. Uccello. 2004. "How Will Boomers Fare at Retirement?" Final Report to the AARP Public Policy Institute. Washington, D.C.: AARP.

Butrica, Barbara A., Howard M. Iams, and Karen E. Smith. 2003. "It's All Relative: Understanding the Retirement Prospects of Baby Boomers." CRR Working Paper No. 2003-21. Chestnut Hill, MA: Center for Retirement Research at Boston College.

Caplan, Craig, and Normandy Brangan. 2004. "Out-of-Pocket Spending on Health Care by Medicare Beneficiaries Age 65 and Older in 2003." AARP Data Digest. Washington, D.C.: AARP Public Policy Institute.

Citro, Constance F., and Robert T. Michael. 1995. Measuring Poverty: A New Approach. Washington, D.C.: National Academy Press.

Crystal, Stephen, Richard W. Johnson, Jeffrey Harman, Usha Sambamoorthi, and Rizie Kumar. 2000. "Out-of-Pocket Health Care Costs Among Older Americans." Journals of Gerontology: Social Sciences 55B (1): S51-S62.

Easterlin, Richard A., Christine MacDonald, and Diane J. Macunovich. 1990. "Retirement Prospects of the Baby Boom Generation: A Different Perspective." The Gerontologist 30(6): 776-783.

Easterlin, Richard A., Christine M. Schaeffer, and Diane J. Macunovich. 1993. "Will the Baby Boomers be Less Well Off Than Their Parents? Income, Wealth, and Family Circumstances Over the Life Cycle in the United States." Population and Development Review 19(3): 497-522.

Gist, John, and Carlos Figueiredo. 2002. "Deeper in Debt Redux: Housing and Nonhousing Debt Burdens.” AARP Data Digest. Washington, D.C.: AARP Public Policy Institute. 
Goldman, Dana P., and James P. Smith. 2001. "Methodological Biases in Estimating the Burden of Out-of-Pocket Expenses." Health Services Research 35(6): 1357-1370.

Goldman, Dana P., and Julie M. Zissimopoulos. 2003. "High Out-of-Pocket Health Care Spending by the Elderly." Health Affairs 22(3): 194-202.

Gross, David J., Lisa Alecxih, Mary Jo Gibson, John Corea, Craig Caplan, and Normandy Brangan. 1999. "Out-of-Pocket Health Spending by Poor and Near-Poor Elderly Medicare Beneficiaries." Health Services Research 34(1): 241-254.

Gustman, Alan L., and Thomas L. Steinmeier. 1999. "Effects of Pensions on Savings: Analysis with Data from the Health and Retirement Study." Carnegie-Rochester Conference Series 50(July): 271-326.

Hamermesh, Daniel S. 1984. "Consumption During Retirement: The Missing Link in the Life Cycle." Review of Economics and Statistics 66(1): 1-7.

Haveman, Robert, Karen Holden, Barbara Wolfe, and Shane Sherlund. 2003. "Have Newly Retired Workers in the U.S. Saved Enough to Maintain Well- Being Through Retirement Years?" Paper presented at 2003 Annual APPAM Research Conference, Washington, D.C.

Hurd, Michael, F. Thomas Juster, James P. Smith. 2003. "Enhancing the Quality of Data on Income: Recent Innovations from the HRS.” Journal of Human Resources 38(3): 758772.

Hurd, Michael, and Susann Rohwedder. 2003. "The Retirement-Consumption Puzzle: Anticipated and Actual Declines in Spending at Retirement." NBER Working Paper No. 9586. Cambridge, MA: National Bureau of Economic Research.

Paulin, Geoffrey D. and Abby L. Duly. 2002. "Planning Ahead: Consumer Expenditure Patterns in Retirement." Monthly Labor Review. July: 38-58.

Paulin, Geoffrey D. 2000. "Expenditure Patterns of Older Americans, 1984-97." Monthly Labor Review. May: 3-28.

Rubin, Rose M. and Michael L. Nieswiadomy. 1997. Expenditures of Older Americans. Westport, CT: Praeger.

Sabelhaus, John, and Joyce Manchester. 1995. "Baby Boomers and Their Parents: How Does Their Economic Well-Being Compare in Middle Age?" The Journal of Human Resources 30(4): 791-806.

Smith, Karen E. 2002. "How Will Recent Patterns of Earnings Inequality Affect Future Retirement Incomes?" Final Report for AARP. Washington, DC: The Urban Institute. 
Uccello, Cori E. 2001. “Are Americans Saving Enough for Retirement?” Issue Brief No. 7. Center for Retirement Research at Boston College.

U.S. Census Bureau. 2004. "Historical Poverty Tables." http://www.census.gov/hhes/poverty/histpov/hstpov3.html (Accessed December 6, 2004).

U.S. Social Security Administration. 2004. Annual Statistical Supplement to the Social Security Bulletin, 2003. Washington, DC: U.S. Social Security Administration.

U.S. Department of Agriculture. 2002. "Official USDA Food Plans: Cost of Food at Home at Four Level, U.S. Average, December 2001." http://www.usda.gov/cnpp/FoodPlans/Updates/fooddec01.pdf (Accessed December 6, 2004). 
Table 1.

Median Per Capita Household Expenditures and Income, by Living Arrangement, Marital Status, and Age

\begin{tabular}{|c|c|c|c|c|c|c|c|c|c|}
\hline & \multicolumn{3}{|c|}{ Married } & \multicolumn{3}{|c|}{ Nonmarried } & \multicolumn{3}{|c|}{ All } \\
\hline & $53-64$ & $65-74$ & $>=75$ & $53-64$ & $65-74$ & $>=75$ & $53-64$ & $65-74$ & $>=75$ \\
\hline \multicolumn{10}{|l|}{ A. All } \\
\hline \multicolumn{10}{|l|}{ Median Level } \\
\hline$\overline{\text { Expenditures }}$ & $\$ 17,409$ & $\$ 15,414$ & $\$ 13,678$ & $\$ 17,196$ & $\$ 17,083$ & $\$ 15,390$ & $\$ 17,350$ & $\$ 15,681$ & $\$ 14,179$ \\
\hline Before-Tax Income & 30,898 & 20,023 & 15,800 & 24,683 & 18,581 & 15,040 & 29,758 & 19,764 & 15,594 \\
\hline After-Tax Income & 27,701 & 19,484 & 15,727 & 23,118 & 18,511 & 15,036 & 26,948 & 19,337 & 15,563 \\
\hline After-Tax Income Plus Assets & 31,366 & 26,040 & 23,620 & 26,070 & 22,794 & 21,140 & 30,436 & 25,434 & 22,809 \\
\hline \multicolumn{10}{|l|}{ Median Share of Expenditures } \\
\hline Housing & $36 \%$ & $31 \%$ & $29 \%$ & $37 \%$ & $36 \%$ & $41 \%$ & $36 \%$ & $32 \%$ & $32 \%$ \\
\hline Health Care & $12 \%$ & $17 \%$ & $19 \%$ & $11 \%$ & $14 \%$ & $18 \%$ & $12 \%$ & $16 \%$ & $20 \%$ \\
\hline Food & $10 \%$ & $13 \%$ & $14 \%$ & $13 \%$ & $17 \%$ & $13 \%$ & $11 \%$ & $14 \%$ & $13 \%$ \\
\hline Clothing & $5 \%$ & $3 \%$ & $2 \%$ & $5 \%$ & $3 \%$ & $3 \%$ & $5 \%$ & $3 \%$ & $2 \%$ \\
\hline Transportation & $14 \%$ & $13 \%$ & $10 \%$ & $13 \%$ & $10 \%$ & $9 \%$ & $14 \%$ & $12 \%$ & $12 \%$ \\
\hline Entertainment & $10 \%$ & $13 \%$ & $10 \%$ & $13 \%$ & $10 \%$ & $6 \%$ & $11 \%$ & $13 \%$ & $8 \%$ \\
\hline Gifts & $8 \%$ & $6 \%$ & $10 \%$ & $5 \%$ & $7 \%$ & $8 \%$ & $7 \%$ & $6 \%$ & $9 \%$ \\
\hline Other & $6 \%$ & $3 \%$ & $7 \%$ & $3 \%$ & $3 \%$ & $2 \%$ & $5 \%$ & $4 \%$ & $5 \%$ \\
\hline Number of Observations & 1,742 & 1,286 & 608 & 615 & 506 & 609 & 2,357 & 1,792 & 1,217 \\
\hline \multicolumn{10}{|c|}{ B. Excludes Adults Living with Nonspouses } \\
\hline \multicolumn{10}{|l|}{ Median Level } \\
\hline$\overline{\text { Expenditures }}$ & $\$ 20,784$ & $\$ 16,897$ & $\$ 14,056$ & $\$ 24,212$ & $\$ 20,431$ & $\$ 17,856$ & $\$ 21,314$ & $\$ 17,459$ & $\$ 15,070$ \\
\hline Before-Tax Income & 32,604 & 20,719 & 15,624 & 27,856 & 18,360 & 15,053 & 31,781 & 20,341 & 15,492 \\
\hline After-Tax Income & 29,115 & 20,039 & 15,562 & 25,768 & 18,300 & 15,047 & 28,477 & 19,787 & 15,445 \\
\hline After-Tax Income Plus Assets & 34,100 & 27,942 & 24,018 & 29,385 & 23,356 & 22,355 & 33,167 & 27,324 & 23,476 \\
\hline \multicolumn{10}{|l|}{ Median Share of Expenditures } \\
\hline Housing & $29 \%$ & $32 \%$ & $28 \%$ & $42 \%$ & $35 \%$ & $38 \%$ & $33 \%$ & $33 \%$ & $29 \%$ \\
\hline Health Care & $12 \%$ & $14 \%$ & $21 \%$ & $10 \%$ & $15 \%$ & $19 \%$ & $12 \%$ & $13 \%$ & $20 \%$ \\
\hline Food & $12 \%$ & $12 \%$ & $13 \%$ & $11 \%$ & $12 \%$ & $11 \%$ & $12 \%$ & $12 \%$ & $13 \%$ \\
\hline Clothing & $4 \%$ & $3 \%$ & $2 \%$ & $4 \%$ & $5 \%$ & $3 \%$ & $3 \%$ & $3 \%$ & $2 \%$ \\
\hline Transportation & $15 \%$ & $12 \%$ & $10 \%$ & $11 \%$ & $13 \%$ & $10 \%$ & $14 \%$ & $12 \%$ & $12 \%$ \\
\hline Entertainment & $15 \%$ & $15 \%$ & $10 \%$ & $13 \%$ & $8 \%$ & $7 \%$ & $14 \%$ & $13 \%$ & $7 \%$ \\
\hline Gifts & $8 \%$ & $7 \%$ & $10 \%$ & $6 \%$ & $9 \%$ & $10 \%$ & $8 \%$ & $8 \%$ & $9 \%$ \\
\hline Other & $5 \%$ & $5 \%$ & $7 \%$ & $1 \%$ & $2 \%$ & $2 \%$ & $4 \%$ & $6 \%$ & $6 \%$ \\
\hline Number of Observations & 1,142 & 1,019 & 541 & 333 & 340 & 471 & 1,475 & 1,359 & 1,012 \\
\hline
\end{tabular}

Note. The median value is measured as the mean value between the 45th and 55th percentiles of the distribution.

Source: Authors' estimates from the Health and Retirement Study. 
Table 2.

Median Per Capita Household Expenditures for Adults Ages 65+, by Marital Status, Income Quintile, and Spending Category, 2001

\begin{tabular}{|c|c|c|c|c|c|c|c|c|c|c|}
\hline & \multirow[b]{2}{*}{$\begin{array}{c}\text { Share of } \\
\text { Sample } \\
(\%) \\
\end{array}$} & \multirow[b]{2}{*}{$\begin{array}{c}\text { Total } \\
\text { Expenditures } \\
(\$)\end{array}$} & \multicolumn{8}{|c|}{ Share of Total Expenditures } \\
\hline & & & $\begin{array}{c}\text { Housing } \\
(\%)\end{array}$ & $\begin{array}{l}\text { Health } \\
\text { Care } \\
(\%) \\
\end{array}$ & $\begin{array}{l}\text { Food } \\
(\%)\end{array}$ & $\begin{array}{c}\text { Clothing } \\
(\%)\end{array}$ & $\begin{array}{c}\text { Transport. } \\
(\%)\end{array}$ & $\begin{array}{c}\text { Entertain. } \\
(\%)\end{array}$ & $\begin{array}{l}\text { Gifts } \\
(\%)\end{array}$ & $\begin{array}{c}\text { Other } \\
(\%)\end{array}$ \\
\hline \multicolumn{11}{|l|}{ A. Married } \\
\hline $\begin{array}{l}\text { All } \\
\text { Income Quintile }\end{array}$ & 100 & 14,792 & 29 & 20 & 13 & 2 & 12 & 10 & 10 & 4 \\
\hline 1st Quintile & 20 & 10,111 & 33 & 22 & 13 & 1 & 10 & 8 & 5 & 8 \\
\hline 2nd Quintile & 20 & 12,809 & 27 & 22 & 18 & 2 & 10 & 11 & 9 & 1 \\
\hline 3rd Quintile & 20 & 15,122 & 26 & 23 & 13 & 3 & 12 & 14 & 8 & 1 \\
\hline 4th Quintile & 20 & 17,393 & 33 & 11 & 11 & 3 & 12 & 18 & 6 & 5 \\
\hline 5th Quintile & 20 & 25,567 & 37 & 14 & 9 & 2 & 10 & 13 & 12 & 3 \\
\hline \multicolumn{11}{|l|}{ B. Nonmarried } \\
\hline $\begin{array}{l}\text { All } \\
\text { Income Quintile }\end{array}$ & 100 & 16,178 & 39 & 16 & 15 & 3 & 9 & 7 & 7 & 3 \\
\hline 1st Quintile & 20 & 9,492 & 40 & 14 & 20 & 5 & 9 & 5 & 7 & 0 \\
\hline 2nd Quintile & 20 & 12,864 & 29 & 24 & 17 & 8 & 8 & 7 & 6 & 1 \\
\hline 3rd Quintile & 20 & 15,579 & 41 & 13 & 11 & 3 & 12 & 8 & 10 & 2 \\
\hline 4th Quintile & 20 & 19,904 & 39 & 12 & 12 & 3 & 12 & 13 & 8 & 2 \\
\hline 5th Quintile & 20 & 27,911 & 42 & 8 & 11 & 2 & 6 & 10 & 18 & 3 \\
\hline
\end{tabular}

Notes: Estimates are based on a sample of 1,894 married adults and 1,115 nonmarried adults, all of whom are ages 65 and older. The median value is measured as the mean value between the 45th and 55th percentiles of the distribution, and all expenditures are expressed in 2001 dollars. Income quintiles are defined on the basis of after-tax income plus the value of annuitized financial assets.

Source: Authors' estimates from the Health and Retirement Study. 
Table 3

Median Per Capita Household Expenditures for Married Adults Ages 65+, by Personal Characteristics and Spending Category, 2001

\begin{tabular}{|c|c|c|c|c|c|c|c|c|c|c|}
\hline & \multirow[b]{2}{*}{$\begin{array}{c}\text { Share of } \\
\text { Sample } \\
(\%)\end{array}$} & \multirow[b]{2}{*}{$\begin{array}{c}\text { Total } \\
\text { Expenditures } \\
(\$)\end{array}$} & \multicolumn{8}{|c|}{ Share of Total Expenditures } \\
\hline & & & $\begin{array}{c}\text { Housing } \\
(\%)\end{array}$ & $\begin{array}{c}\text { Health } \\
\text { Care } \\
(\%)\end{array}$ & $\begin{array}{c}\text { Food } \\
(\%)\end{array}$ & $\begin{array}{c}\text { Clothing } \\
(\%)\end{array}$ & $\begin{array}{c}\text { Transport. } \\
(\%)\end{array}$ & $\begin{array}{c}\text { Entertain. } \\
(\%)\end{array}$ & $\begin{array}{l}\text { Gifts } \\
(\%)\end{array}$ & $\begin{array}{c}\text { Other } \\
(\%)\end{array}$ \\
\hline \multicolumn{10}{|l|}{ Age } & 4 \\
\hline $65-74$ & 66 & 15,414 & 31 & 17 & 13 & 3 & 13 & 13 & 6 & 3 \\
\hline$>=75$ & 34 & 13,678 & 29 & 19 & 14 & 2 & 10 & 10 & 10 & 7 \\
\hline \multicolumn{11}{|l|}{ Race } \\
\hline White,Other & 92 & 15,189 & 27 & 19 & 13 & 2 & 13 & 11 & 9 & 5 \\
\hline Black & 5 & 12,024 & 44 & 21 & 10 & 0 & 12 & 2 & 12 & 0 \\
\hline Hispanic & 4 & 7,125 & 42 & 14 & 9 & 1 & 21 & 9 & 2 & 1 \\
\hline \multicolumn{11}{|l|}{ Education } \\
\hline$<\mathrm{HS}$ & 24 & 10,346 & 34 & 17 & 14 & 2 & 14 & 8 & 9 & 2 \\
\hline HS & 35 & 13,967 & 31 & 20 & 13 & 2 & 11 & 10 & 11 & 4 \\
\hline$>\mathrm{HS}$ & 41 & 19,211 & 28 & 11 & 12 & 2 & 9 & 15 & 10 & 13 \\
\hline \multicolumn{11}{|l|}{ Sex } \\
\hline Male & 57 & 15,012 & 29 & 18 & 14 & 2 & 12 & 12 & 9 & 4 \\
\hline Female & 43 & 14,509 & 29 & 20 & 13 & 2 & 12 & 9 & 11 & 4 \\
\hline \multicolumn{11}{|l|}{ Self-Reported Health } \\
\hline Excellent / Very Good & 44 & 17,134 & 31 & 13 & 11 & 3 & 12 & 14 & 7 & 7 \\
\hline Good & 31 & 14,036 & 29 & 19 & 13 & 2 & 12 & 10 & 8 & 7 \\
\hline $\begin{array}{l}\text { Fair / Poor } \\
\text { Health Insurance }\end{array}$ & 25 & 12,499 & 36 & 22 & 16 & 4 & 9 & 5 & 5 & 2 \\
\hline Employer Sponsored & 45 & 16,210 & 26 & 14 & 13 & 3 & 12 & 14 & 7 & 10 \\
\hline Nongroup & 26 & 14,533 & 25 & 28 & 13 & 1 & 11 & 7 & 11 & 5 \\
\hline Medicaid & 2 & 5,832 & 47 & 2 & 17 & 4 & 5 & 4 & 18 & 3 \\
\hline Medicare Only & 27 & 13,597 & 35 & 17 & 14 & 5 & 10 & 8 & 9 & 2 \\
\hline \multicolumn{11}{|l|}{ Housing Tenure } \\
\hline Owner / No Mortgage & 64 & 13,274 & 28 & 19 & 16 & 3 & 10 & 11 & 10 & 3 \\
\hline Owner / Mortqage & 25 & 19,639 & 39 & 11 & 12 & 2 & 11 & 9 & 9 & 7 \\
\hline Renter & 11 & 13,999 & 34 & 25 & 12 & 2 & 9 & 8 & 5 & 5 \\
\hline \multicolumn{11}{|l|}{ Urban/Rural } \\
\hline Urban & 40 & 15,957 & 30 & 18 & 14 & 2 & 13 & 14 & 8 & 2 \\
\hline Suburban & 29 & 15,903 & 28 & 15 & 11 & 3 & 13 & 16 & 7 & 6 \\
\hline Rural & 31 & 12,600 & 37 & 15 & 15 & 2 & 11 & 9 & 7 & 5 \\
\hline
\end{tabular}

Notes: Estimates are based on a sample of 1,894 married adults ages 65 and older. The median value is measured as the mean value between the 45 th and 55 th percentiles of the distribution, and all expenditures are expressed in 2001 dollars.

Source: Authors' estimates from the Health and Retirement Study. 
Table 4

Median Per Capita Household Expenditures for Nonmarried Adults Ages 65+,

by Personal Characteristics and Spending Category, 2001

\begin{tabular}{|c|c|c|c|c|c|c|c|c|c|c|}
\hline & \multirow[b]{2}{*}{$\begin{array}{c}\text { Share of } \\
\text { Sample } \\
(\%)\end{array}$} & \multirow[b]{2}{*}{$\begin{array}{c}\text { Total } \\
\text { Expenditures } \\
(\$) \\
\end{array}$} & \multicolumn{8}{|c|}{ Share of Total Expenditures } \\
\hline & & & $\begin{array}{c}\text { Housing } \\
(\%)\end{array}$ & $\begin{array}{c}\text { Health } \\
\text { Care } \\
(\%) \\
\end{array}$ & $\begin{array}{c}\text { Food } \\
(\%)\end{array}$ & $\begin{array}{c}\text { Clothing } \\
(\%)\end{array}$ & $\begin{array}{c}\text { Transport. } \\
(\%)\end{array}$ & $\begin{array}{c}\text { Entertain. } \\
(\%)\end{array}$ & $\begin{array}{c}\text { Gifts } \\
(\%)\end{array}$ & $\begin{array}{c}\text { Other } \\
(\%)\end{array}$ \\
\hline $\begin{array}{l}\text { All } \\
\text { Age }\end{array}$ & 100 & 16,178 & 39 & 16 & 15 & 3 & 9 & 7 & 7 & 3 \\
\hline $65-74$ & 46 & 17,083 & 36 & 14 & 17 & 3 & 10 & 10 & 7 & 3 \\
\hline $\begin{array}{l}>=75 \\
\text { Race }\end{array}$ & 54 & 15,390 & 41 & 18 & 13 & 3 & 9 & 6 & 8 & 2 \\
\hline White,Other & 84 & 17,101 & 38 & 17 & 13 & 3 & 9 & 8 & 8 & 3 \\
\hline $\begin{array}{l}\text { Black } \\
\text { Hispanic } \\
\text { Education }\end{array}$ & $\begin{array}{c}10 \\
6\end{array}$ & $\begin{array}{r}13,636 \\
8,405\end{array}$ & $\begin{array}{l}61 \\
50\end{array}$ & $\begin{array}{c}15 \\
5\end{array}$ & $\begin{array}{c}7 \\
19\end{array}$ & $\begin{array}{l}3 \\
1\end{array}$ & $\begin{array}{c}6 \\
20\end{array}$ & $\begin{array}{l}3 \\
3\end{array}$ & $\begin{array}{l}3 \\
1\end{array}$ & $\begin{array}{l}1 \\
1\end{array}$ \\
\hline$<\mathrm{HS}$ & 32 & 12,503 & 44 & 17 & 15 & 4 & 9 & 5 & 5 & 0 \\
\hline $\mathrm{HS}$ & 34 & 15,047 & 41 & 15 & 14 & 3 & 11 & 7 & 7 & 3 \\
\hline $\begin{array}{l}>\mathrm{HS} \\
\text { Marital Status }\end{array}$ & 34 & 22,573 & 40 & 13 & 10 & 4 & 11 & 11 & 10 & 2 \\
\hline Separated/Divorced & 22 & 15,316 & 38 & 15 & 20 & 3 & 9 & 6 & 5 & 4 \\
\hline Widowed & 70 & 16,683 & 40 & 19 & 12 & 3 & 9 & 7 & 8 & 3 \\
\hline $\begin{array}{l}\text { Never Married } \\
\text { Sex }\end{array}$ & 7 & 15,275 & 46 & 20 & 13 & 4 & 7 & 4 & 5 & 2 \\
\hline Male & 23 & 16,597 & 38 & 15 & 23 & 1 & 7 & 10 & 5 & 0 \\
\hline $\begin{array}{l}\text { Female } \\
\text { Self-Reported Health }\end{array}$ & 77 & 16,021 & 39 & 17 & 12 & 4 & 10 & 6 & 8 & 4 \\
\hline Excellent / Very Good & 39 & 17,574 & 38 & 15 & 12 & 3 & 11 & 10 & 8 & 4 \\
\hline Good & 35 & 16,191 & 39 & 17 & 18 & 2 & 8 & 7 & 7 & 2 \\
\hline $\begin{array}{l}\text { Fair / Poor } \\
\text { Health Insurance }\end{array}$ & 26 & 14,687 & 37 & 17 & 18 & 4 & 11 & 6 & 6 & 2 \\
\hline Employer Sponsored & 30 & 19,741 & 33 & 15 & 13 & 3 & 14 & 8 & 12 & 2 \\
\hline Nongroup & 29 & 17,247 & 40 & 21 & 12 & 2 & 9 & 7 & 8 & 1 \\
\hline Medicaid & 10 & 8,784 & 42 & 12 & 18 & 3 & 13 & 8 & 3 & 0 \\
\hline $\begin{array}{l}\text { Medicare Only } \\
\text { Housing Tenure }\end{array}$ & 31 & 14,514 & 40 & 14 & 13 & 4 & 13 & 7 & 7 & 1 \\
\hline Owner / No Mortgage & 51 & 15,602 & 37 & 19 & 12 & 3 & 11 & 6 & 7 & 3 \\
\hline Owner / Mortgage & 19 & 23,693 & 46 & 11 & 12 & 5 & 7 & 12 & 6 & 1 \\
\hline $\begin{array}{l}\text { Renter } \\
\text { Urban/Rural }\end{array}$ & 30 & 14,077 & 42 & 15 & 18 & 4 & 8 & 6 & 5 & 2 \\
\hline Urban & 42 & 17,309 & 38 & 15 & 13 & 2 & 10 & 10 & 9 & 3 \\
\hline Suburban & 30 & 15,624 & 45 & 13 & 12 & 3 & 11 & 6 & 8 & 1 \\
\hline Rural & 28 & 15,053 & 35 & 20 & 15 & 5 & 13 & 4 & 5 & 3 \\
\hline
\end{tabular}

Notes: Estimates are based on a sample of 1,115 nonmarried adults ages 65 and older. The median value is measured as the mean value between the 45 th and 55 th percentiles of the distribution, and all expenditures are expressed in 2001 dollars.

Source: Authors' estimates from the Health and Retirement Study. 
Table 5.

Distribution of Mean Per Capita Household Expenditures for Adults Ages 65+, by Marital Status, Percentile, and Spending Category, 2001

\begin{tabular}{|c|c|c|c|c|c|c|c|c|c|}
\hline & \multirow[b]{2}{*}{$\begin{array}{c}\text { Total } \\
\text { Expenditures } \\
(\$)\end{array}$} & \multicolumn{8}{|c|}{ Share of Total Expenditures } \\
\hline & & $\begin{array}{c}\text { Housing } \\
(\%)\end{array}$ & $\begin{array}{c}\text { Health } \\
\text { Care } \\
(\%) \\
\end{array}$ & $\begin{array}{c}\text { Food } \\
(\%) \\
\end{array}$ & $\begin{array}{c}\text { Clothing } \\
(\%)\end{array}$ & $\begin{array}{c}\text { Transport. } \\
(\%) \\
\end{array}$ & $\begin{array}{c}\text { Entertain. } \\
(\%)\end{array}$ & $\begin{array}{c}\text { Gifts } \\
(\%) \\
\end{array}$ & $\begin{array}{c}\text { Other } \\
(\%)\end{array}$ \\
\hline \multicolumn{10}{|l|}{ A. Married } \\
\hline \multicolumn{10}{|l|}{ Percentile } \\
\hline 5th - 15th & 6,487 & 35 & 16 & 16 & 3 & 14 & 8 & 7 & 2 \\
\hline 20th - 30th & 9,881 & 33 & 18 & 14 & 2 & 12 & 9 & 9 & 3 \\
\hline 45th - 55th & 14,792 & 29 & 20 & 13 & 2 & 12 & 10 & 10 & 4 \\
\hline 70th - 80th & 24,016 & 30 & 13 & 9 & 2 & 12 & 12 & 8 & 13 \\
\hline 85th - 95th & 38,749 & 28 & 13 & 6 & 3 & 9 & 12 & 15 & 14 \\
\hline \multicolumn{10}{|c|}{ B. Nonmarried } \\
\hline \multicolumn{10}{|l|}{ Percentile } \\
\hline 5 th - 15th & 5,626 & 47 & 13 & 17 & 3 & 8 & 4 & 6 & 2 \\
\hline 20th - 30th & 9,746 & 38 & 19 & 13 & 4 & 10 & 7 & 8 & 2 \\
\hline 45th - 55th & 16,178 & 39 & 16 & 15 & 3 & 9 & 7 & 7 & 3 \\
\hline 70th - 80th & 27,555 & 37 & 13 & 12 & 4 & 9 & 8 & 12 & 5 \\
\hline 85th - 95th & 46,746 & 28 & 16 & 8 & 2 & 10 & 11 & 14 & 12 \\
\hline
\end{tabular}

Notes: Estimates are based on a sample of 1,894 married adults and 1,115 nonmarried adults, all of whom are ages 65 and older. The median value is measured as the mean value between the 45th and 55th percentiles of the distribution, and all expenditures are expressed in 2001 dollars.

Source: Authors' estimates from the Health and Retirement Study. 
Table 6.

Share of Median Household Expenditures Devoted to Housing by Married Adults Ages 65+, by Spending Category, 2001

\begin{tabular}{|c|c|c|c|c|c|c|c|}
\hline & $\begin{array}{c}\text { Total } \\
\text { Housing } \\
(\%) \\
\end{array}$ & $\begin{array}{c}\text { Mortgage } \\
(\%) \\
\end{array}$ & $\begin{array}{c}\text { Insurance } \\
(\%)\end{array}$ & $\begin{array}{l}\text { Property } \\
\text { Tax }(\%) \\
\end{array}$ & Rent & Utilities (\%) & $\begin{array}{c}\text { Maintenance } \\
(\%) \\
\end{array}$ \\
\hline $\begin{array}{l}\text { All } \\
\text { Housing Tenure }\end{array}$ & 29 & 5 & 2 & 6 & 1 & 9 & 5 \\
\hline Owner / No Mortqage & 28 & 0 & 3 & 8 & 0 & 11 & 6 \\
\hline Owner / Mortgage & 39 & 18 & 3 & 5 & 0 & 9 & 5 \\
\hline $\begin{array}{l}\text { Renter } \\
\text { Age }\end{array}$ & 34 & 0 & 1 & 2 & 13 & 9 & 9 \\
\hline $65-74$ & 31 & 8 & 2 & 5 & 1 & 10 & 5 \\
\hline $\begin{array}{l}>=75 \\
\text { Race }\end{array}$ & 29 & 2 & 2 & 5 & 2 & 11 & 7 \\
\hline White,Other & 27 & 5 & 2 & 5 & 1 & 9 & 4 \\
\hline Black & 44 & 21 & 3 & 3 & 0 & 13 & 4 \\
\hline $\begin{array}{l}\text { Hispanic } \\
\text { Education }\end{array}$ & 42 & 11 & 5 & 3 & 7 & 10 & 6 \\
\hline$<\mathrm{HS}$ & 34 & 6 & 3 & 6 & 2 & 12 & 6 \\
\hline $\mathrm{HS}$ & 31 & 4 & 2 & 6 & 2 & 10 & 7 \\
\hline $\begin{array}{l}>\mathrm{HS} \\
\text { Urban/Rural }\end{array}$ & 28 & 6 & 2 & 5 & 3 & 8 & 5 \\
\hline Urban & 30 & 6 & 2 & 7 & 3 & 8 & 5 \\
\hline Suburban & 28 & 7 & 2 & 5 & 1 & 8 & 6 \\
\hline $\begin{array}{l}\text { Rural } \\
\text { Income Quintile }\end{array}$ & 37 & 5 & 3 & 9 & 1 & 13 & 6 \\
\hline 1st Quintile & 33 & 6 & 2 & 3 & 5 & 13 & 5 \\
\hline 2nd Quintile & 27 & 2 & 2 & 6 & 2 & 10 & 6 \\
\hline 3rd Quintile & 26 & 5 & 2 & 5 & 1 & 9 & 4 \\
\hline 4th Quintile & 33 & 8 & 2 & 8 & 2 & 9 & 6 \\
\hline 5th Quintile & 37 & 13 & 1 & 5 & 5 & 6 & 7 \\
\hline
\end{tabular}

Notes: Estimates are based on a sample of 1,894 married adults ages 65 and older. The median value is measured as the mean value between the 45th and 55th percentiles of the distribution, and all expenditures are expressed in 2001 dollars. Income quintiles are defined on the basis of after-tax income plus the value of annuitized financial assets.

Source: Authors' estimates from the Health and Retirement Study. 
Table 7.

Share of Median Household Expenditures Devoted to Housing by Nonmarried Adults Ages 65+, by Spending Category, 2001

\begin{tabular}{|c|c|c|c|c|c|c|c|}
\hline & $\begin{array}{c}\text { Total } \\
\text { Housing } \\
(\%) \\
\end{array}$ & $\begin{array}{c}\text { Mortgage } \\
(\%) \\
\end{array}$ & $\begin{array}{c}\text { Insurance } \\
(\%)\end{array}$ & $\begin{array}{c}\text { Property } \\
\text { Tax } \\
(\%) \\
\end{array}$ & $\begin{array}{c}\text { Rent } \\
(\%)\end{array}$ & Utilities (\%) & $\begin{array}{c}\text { Maintenance } \\
(\%)\end{array}$ \\
\hline $\begin{array}{l}\text { All } \\
\text { Housing Tenure }\end{array}$ & 39 & 3 & 2 & 5 & 9 & 13 & 7 \\
\hline Owner / No Mortgage & 37 & 0 & 2 & 9 & 0 & 15 & 11 \\
\hline Owner / Mortgage & 46 & 19 & 3 & 7 & 0 & 10 & 5 \\
\hline Renter & 42 & 0 & 0 & 1 & 27 & 11 & 3 \\
\hline \multicolumn{8}{|l|}{ Age } \\
\hline $65-74$ & 36 & 5 & 1 & 4 & 9 & 12 & 4 \\
\hline \multicolumn{8}{|l|}{ Race } \\
\hline White,Other & 38 & 3 & 2 & 6 & 9 & 13 & 5 \\
\hline Black & 61 & 16 & 1 & 14 & 13 & 14 & 3 \\
\hline Hispanic & 50 & 9 & 0 & 3 & 26 & 10 & 2 \\
\hline \multicolumn{8}{|l|}{ Education } \\
\hline$<\mathrm{HS}$ & 44 & 4 & 1 & 4 & 16 & 16 & 2 \\
\hline HS & 41 & 3 & 2 & 6 & 9 & 12 & 9 \\
\hline$>\mathrm{HS}$ & 40 & 7 & 2 & 6 & 7 & 10 & 7 \\
\hline \multicolumn{8}{|l|}{ Marital Status } \\
\hline Separated/Divorced & 38 & 4 & 1 & 5 & 8 & 11 & 10 \\
\hline Widowed & 40 & 3 & 3 & 6 & 7 & 14 & 7 \\
\hline $\begin{array}{l}\text { Never Married } \\
\text { Sex }\end{array}$ & 46 & 5 & 1 & 1 & 20 & 11 & 8 \\
\hline Male & 38 & 5 & 1 & 5 & 13 & 9 & 5 \\
\hline Female & 39 & 3 & 2 & 5 & 7 & 13 & 8 \\
\hline \multicolumn{8}{|l|}{ Urban/Rural } \\
\hline Urban & 38 & 3 & 2 & 6 & 12 & 10 & 5 \\
\hline Suburban & 45 & 5 & 3 & 4 & 10 & 14 & 10 \\
\hline Rural & 35 & 2 & 2 & 3 & 6 & 14 & 8 \\
\hline \multicolumn{8}{|l|}{ Income Quintile } \\
\hline 1st Quintile & 40 & 2 & 1 & 2 & 16 & 16 & 4 \\
\hline 2nd Quintile & 29 & 1 & 2 & 3 & 8 & 12 & 4 \\
\hline 3rd Quintile & 41 & 4 & 2 & 4 & 18 & 10 & 4 \\
\hline 4th Quintile & 39 & 8 & 3 & 7 & 5 & 11 & 6 \\
\hline 5th Quintile & 42 & 8 & 3 & 5 & 15 & 7 & 4 \\
\hline
\end{tabular}

Notes: Estimates are based on a sample of 1,115 nonmarried adults ages 65 and older. The median value is measured as the mean value between the 45th and 55th percentiles of the distribution, and all expenditures are expressed in 2001 dollars. Income quintiles are defined on the basis of after-tax income plus the value of annuitized financial assets.

Source: Authors' estimates from the Health and Retirement Study. 
Table 8.

Share of Median Household Expenditures Devoted to Health Care

by Married Adults Ages 65+, by Spending Category, 2001

\begin{tabular}{|c|c|c|c|c|c|}
\hline & $\begin{array}{c}\text { Total Health } \\
\text { Care (\%) }\end{array}$ & Premiums (\%) & $\begin{array}{c}\text { Drugs } \\
(\%)\end{array}$ & $\begin{array}{c}\text { Health } \\
\text { Services } \\
(\%) \\
\end{array}$ & $\begin{array}{c}\text { Medical } \\
\text { Supplies } \\
(\%)\end{array}$ \\
\hline All & 20 & 8 & 6 & 4 & 1 \\
\hline \multicolumn{6}{|l|}{ Self-Reported Health } \\
\hline Excellent / Very Good & 13 & 5 & 4 & 3 & 1 \\
\hline Good & 19 & 9 & 5 & 3 & 1 \\
\hline $\begin{array}{l}\text { Fair / Poor } \\
\text { Health Insurance }\end{array}$ & 22 & 7 & 8 & 5 & 1 \\
\hline Employer Sponsored & 14 & 6 & 3 & 4 & 1 \\
\hline Nongroup & 28 & 11 & 11 & 4 & 1 \\
\hline Medicaid & 2 & 1 & 0 & 0 & 0 \\
\hline Medicare Only & 17 & 6 & 6 & 4 & 1 \\
\hline \multicolumn{6}{|l|}{ Age } \\
\hline $65-74$ & 17 & 7 & 5 & 4 & 1 \\
\hline$>=75$ & 19 & 8 & 6 & 4 & 1 \\
\hline \multicolumn{6}{|l|}{ Race } \\
\hline White,Other & 19 & 8 & 6 & 4 & 1 \\
\hline Black & 21 & 3 & 6 & 8 & 4 \\
\hline Hispanic & 14 & 2 & 4 & 6 & 2 \\
\hline \multicolumn{6}{|l|}{ Education } \\
\hline$<\mathrm{HS}$ & 17 & 8 & 5 & 4 & 1 \\
\hline $\mathrm{HS}$ & 20 & 7 & 7 & 4 & 1 \\
\hline$>\mathrm{HS}$ & 11 & 5 & 2 & 3 & 1 \\
\hline \multicolumn{6}{|l|}{ Urban/Rural } \\
\hline Urban & 18 & 8 & 4 & 4 & 2 \\
\hline Suburban & 15 & 7 & 5 & 3 & 1 \\
\hline $\begin{array}{l}\text { Rural } \\
\text { Income Quintile }\end{array}$ & 15 & \multicolumn{3}{|c|}{ Income Quintile } & 1 \\
\hline 1st Quintile & 22 & 11 & 7 & 4 & 1 \\
\hline 2nd Quintile & 22 & 8 & 6 & 7 & 2 \\
\hline 3rd Quintile & 23 & 10 & 9 & 3 & 1 \\
\hline 4th Quintile & 11 & 4 & 4 & 3 & 0 \\
\hline 5th Quintile & 14 & 8 & 2 & 2 & 1 \\
\hline
\end{tabular}

Notes: Estimates are based on a sample of 1,894 married adults ages 65 and older. The median value is measured as the mean value between the 45th and 55th percentiles of the distribution, and all expenditures are expressed in 2001 dollars. Income quintiles are defined on the basis of after-tax income plus the value of annuitized financial assets.

Source: Authors' estimates from the Health and Retirement Study. 
Table 9.

Share of Median Household Expenditures Devoted to Health Care

by Nonmarried Adults Ages 65+, by Spending Category, 2001

\begin{tabular}{|c|c|c|c|c|c|}
\hline & $\begin{array}{c}\text { Total Health } \\
\text { Care (\%) } \\
\end{array}$ & Premiums (\%) & $\begin{array}{l}\text { Drugs } \\
(\%)\end{array}$ & $\begin{array}{c}\text { Health } \\
\text { Services } \\
(\%) \\
\end{array}$ & $\begin{array}{c}\text { Medical } \\
\text { Supplies } \\
(\%) \\
\end{array}$ \\
\hline All & 16 & 6 & 6 & 3 & 1 \\
\hline \multicolumn{6}{|l|}{ Self-Reported Health } \\
\hline Excellent / Very Good & 15 & 8 & 3 & 3 & 1 \\
\hline Good & 17 & 6 & 6 & 5 & 1 \\
\hline $\begin{array}{l}\text { Fair / Poor } \\
\text { Health Insurance }\end{array}$ & \multicolumn{4}{|c|}{ Health Insurance } & 1 \\
\hline Employer Sponsored & 15 & 6 & 4 & 4 & 1 \\
\hline Nongroup & 21 & 10 & 7 & 3 & 1 \\
\hline Medicaid & 12 & 5 & 7 & 0 & 0 \\
\hline $\begin{array}{l}\text { Medicare Only } \\
\text { Age }\end{array}$ & \multicolumn{4}{|c|}{ Age } & 0 \\
\hline $65-74$ & 14 & 5 & 6 & 3 & 0 \\
\hline $\begin{array}{l}>=75 \\
\text { Race }\end{array}$ & \multicolumn{4}{|c|}{ Race } & 1 \\
\hline White, Other & 17 & 7 & 6 & 3 & 1 \\
\hline Black & 15 & 3 & 6 & 4 & 2 \\
\hline \multicolumn{6}{|l|}{ Education } \\
\hline$<\mathrm{HS}$ & 17 & 7 & 7 & 3 & 1 \\
\hline HS & 15 & 7 & 6 & 2 & 0 \\
\hline$>\mathrm{HS}$ & 13 & 5 & 4 & 3 & 1 \\
\hline \multicolumn{6}{|l|}{ Marital Status } \\
\hline Separated/Divorced & 15 & 3 & 7 & 4 & 1 \\
\hline Widowed & 19 & 8 & 7 & 3 & 1 \\
\hline Never Married & 20 & 7 & 8 & 3 & 2 \\
\hline \multicolumn{6}{|l|}{ Sex } \\
\hline Male & 15 & 6 & 6 & 2 & 1 \\
\hline Female & 17 & 7 & 6 & 4 & 1 \\
\hline \multicolumn{6}{|l|}{ Urban/Rural } \\
\hline Urban & 15 & 6 & 5 & 4 & 0 \\
\hline Suburban & 13 & 5 & 4 & 2 & 1 \\
\hline Rural & 20 & 10 & 7 & 2 & 1 \\
\hline \multicolumn{6}{|l|}{ Income Quintile } \\
\hline 1st Quintile & 14 & 6 & 7 & 1 & 1 \\
\hline 2nd Quintile & 24 & 12 & 7 & 4 & 2 \\
\hline 3rd Quintile & 13 & 6 & 5 & 2 & 1 \\
\hline 4th Quintile & 12 & 6 & 3 & 3 & 1 \\
\hline 5th Quintile & 8 & 3 & 3 & 2 & 0 \\
\hline
\end{tabular}

Notes: Estimates are based on a sample of 1,115 nonmarried adults ages 65 and older. The median value is measured as the mean value between the 45th and 55th percentiles of the distribution, and all expenditures are expressed in 2001 dollars. Income quintiles are defined on the basis of after-tax income plus the value of annuitized financial assets.

Source: Authors' estimates from the Health and Retirement Study. 
Table 10.

Median Per Capita Household Expenditures, Income, and Expenditure to Income Ratios for Married Adults Ages 65+, by Personal Characteristics, 2001

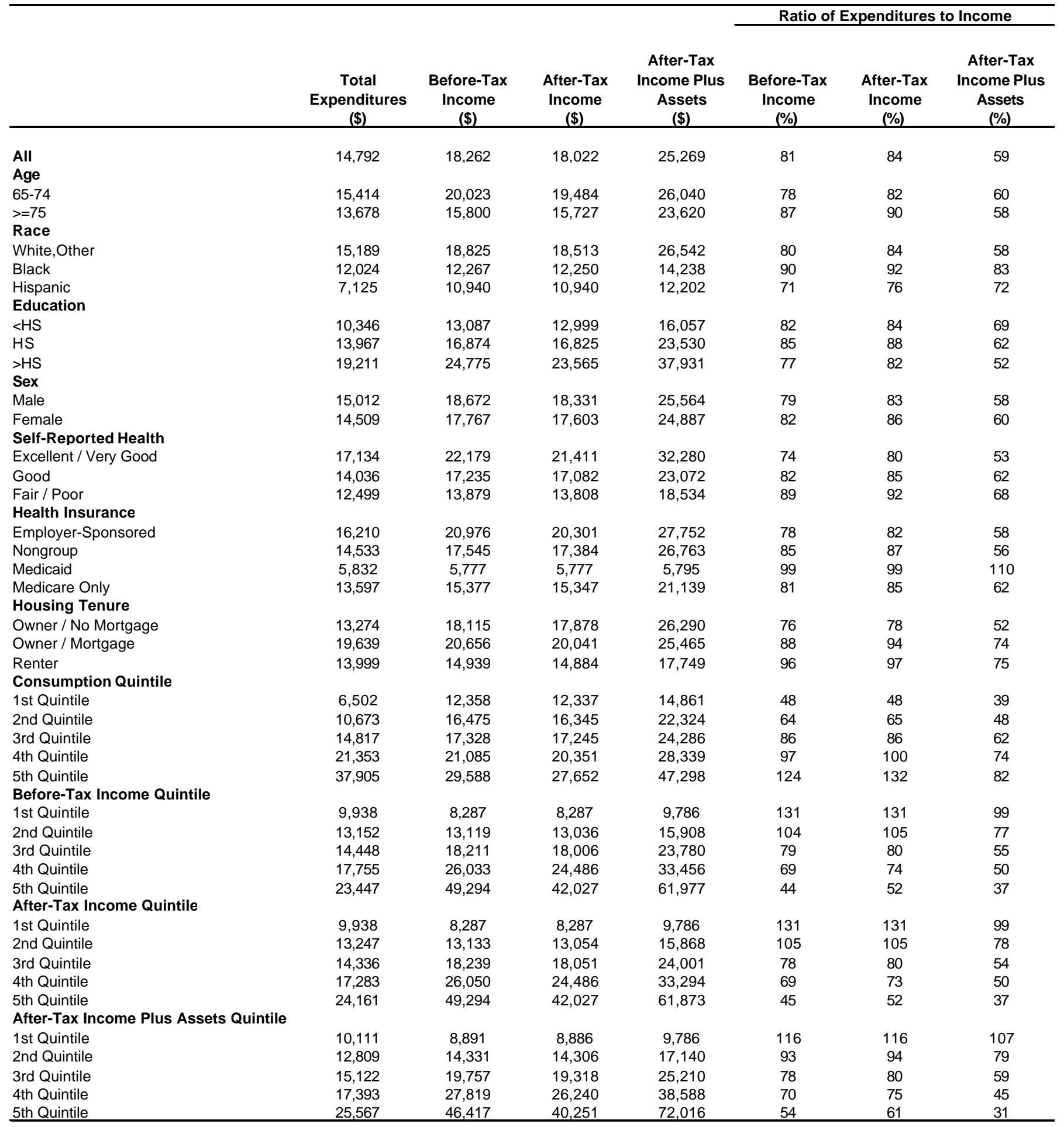

Notes: Estimates are based on a sample of 1,894 married adults ages 65 and older. The median value is measured as the mean value between the 45 th and 55 th percentiles of the distribution.

Source: Authors' estimates from the Health and Retirement Study. 
Table 11.

Median Per Capita Household Expenditures, Income, and Expenditure to Income Ratios for Nonmarried Adults Ages 65+, by Personal Characteristics, 2001

\begin{tabular}{|c|c|c|c|c|c|c|c|}
\hline & \multirow[b]{2}{*}{$\begin{array}{c}\text { Total } \\
\text { Expenditures } \\
(\$) \\
\end{array}$} & \multirow[b]{2}{*}{$\begin{array}{l}\text { Before-Tax } \\
\text { Income } \\
(\$)\end{array}$} & \multirow[b]{2}{*}{$\begin{array}{c}\text { After-Tax } \\
\text { Income } \\
(\$)\end{array}$} & \multirow[b]{2}{*}{$\begin{array}{l}\text { After-Tax } \\
\text { Income Plus } \\
\text { Assets } \\
(\$)\end{array}$} & \multicolumn{3}{|c|}{ Ratio of Expenditures to Income } \\
\hline & & & & & $\begin{array}{c}\text { Before-Tax } \\
\text { Income } \\
(\%) \\
\end{array}$ & $\begin{array}{c}\text { After-Tax } \\
\text { Income } \\
(\%) \\
\end{array}$ & $\begin{array}{c}\text { After-Tax } \\
\text { Income Plus } \\
\text { Assets } \\
(\%)\end{array}$ \\
\hline $\begin{array}{l}\text { All } \\
\text { Age }\end{array}$ & 16,178 & 16,494 & 16,466 & 21,945 & 90 & 92 & 68 \\
\hline $65-74$ & 17,083 & 18,581 & 18,511 & 22,794 & 83 & 86 & 67 \\
\hline $\begin{array}{l}>=75 \\
\text { Race }\end{array}$ & 15,390 & 15,040 & 15,036 & 21,140 & 95 & 96 & 70 \\
\hline White,Other & 17,101 & 17,675 & 17,613 & 24,487 & 89 & 91 & 67 \\
\hline Black & 13,636 & 13,245 & 13,223 & 13,804 & 90 & 92 & 87 \\
\hline $\begin{array}{l}\text { Hispanic } \\
\text { Education }\end{array}$ & 8,405 & 7,964 & 7,964 & 8,058 & 94 & 94 & 80 \\
\hline $\begin{array}{l}<\mathrm{HS} \\
\mathrm{HS}\end{array}$ & $\begin{array}{l}12,503 \\
15,047\end{array}$ & $\begin{array}{l}11,440 \\
15,779\end{array}$ & $\begin{array}{l}11,440 \\
15,753\end{array}$ & $\begin{array}{l}13,094 \\
21,011\end{array}$ & $\begin{array}{l}95 \\
92\end{array}$ & $\begin{array}{l}96 \\
95\end{array}$ & $\begin{array}{l}83 \\
69\end{array}$ \\
\hline $\begin{array}{l}>\mathrm{HS} \\
\text { Marital Status }\end{array}$ & 22,573 & 25,505 & 24,621 & 39,606 & 82 & 87 & 58 \\
\hline Separated/Divorced & 15,316 & 15,903 & 15,894 & 18,986 & 86 & 88 & 70 \\
\hline Widowed & 16,683 & 16,510 & 16,484 & 22,556 & 92 & 94 & 70 \\
\hline Never Married & 15,275 & 19,301 & 19,031 & 26,339 & 71 & 74 & 56 \\
\hline Sex & & & & & & & \\
\hline Male & 16,597 & 23,331 & 23,026 & 29,787 & 71 & 75 & 53 \\
\hline Female & 16,021 & 14,780 & 14,773 & 19,713 & 96 & 97 & 74 \\
\hline Self-Reported Health & & & & & & & \\
\hline Excellent / Very Good & 17,574 & 20,691 & 20,497 & 29,346 & 80 & 82 & 59 \\
\hline Good & 16,191 & 15,742 & 15,742 & 20,700 & 92 & 92 & 70 \\
\hline $\begin{array}{l}\text { Fair / Poor } \\
\text { Health Insurance }\end{array}$ & 14,687 & 12,273 & 12,273 & 14,711 & 110 & 110 & 89 \\
\hline Employer-Sponsored & 19,741 & 23,186 & 22,765 & 32,142 & 79 & 82 & 60 \\
\hline Nongroup & 17,247 & 17,244 & 17,206 & 25,347 & 90 & 91 & 67 \\
\hline Medicaid & 8,784 & 6,882 & 6,882 & 7,014 & 107 & 107 & 106 \\
\hline Medicare Only & 14,514 & 13,939 & 13,932 & 18,180 & 97 & 99 & 74 \\
\hline Housing Tenure & & & & & & & \\
\hline Owner / No Mortgage & 15,602 & 16,387 & 16,366 & 24,798 & 86 & 88 & 61 \\
\hline Owner / Mortgage & 23,693 & 23,436 & 23,086 & 27,047 & 83 & 87 & 71 \\
\hline $\begin{array}{l}\text { Renter } \\
\text { Consumption Quintil }\end{array}$ & 14,077 & 12,706 & 12,704 & 15,427 & 101 & 101 & 83 \\
\hline 1st Quintile & 5,667 & 10,073 & 10,073 & 11,096 & 50 & 50 & 43 \\
\hline 2nd Quintile & 10,841 & 14,418 & 14,418 & 19,937 & 75 & 75 & 57 \\
\hline 3rd Quintile & 16,283 & 16,420 & 16,420 & 21,047 & 100 & 101 & 78 \\
\hline 4th Quintile & 24,800 & 21,519 & 21,079 & 29,261 & 113 & 116 & 82 \\
\hline 5th Quintile & 46,085 & 29,025 & 28,054 & 43,184 & 173 & 183 & 111 \\
\hline Before-Tax Income $\mathrm{C}$ & & & & & & & \\
\hline 1st Quintile & 9,771 & 6,863 & 6,863 & 7,137 & 132 & 132 & 113 \\
\hline 2nd Quintile & 13,457 & 11,493 & 11,493 & 12,712 & 120 & 120 & 97 \\
\hline 3rd Quintile & 15,427 & 16,463 & 16,441 & 19,770 & 89 & 90 & 69 \\
\hline 4th Quintile & 19,504 & 24,485 & 24,012 & 31,014 & 79 & 80 & 58 \\
\hline 5th Quintile & 27,188 & 47,344 & 42,658 & 64,160 & 51 & 57 & 37 \\
\hline After-Tax Income Qu & & & & & & & \\
\hline 1st Quintile & 9,771 & 6,863 & 6,863 & 7,137 & 132 & 132 & 113 \\
\hline 2nd Quintile & 13,457 & 11,493 & 11,493 & 12,712 & 120 & 120 & 97 \\
\hline 3rd Quintile & 15,577 & 16,463 & 16,441 & 19,771 & 90 & 91 & 69 \\
\hline 4th Quintile & 19,323 & 24,485 & 24,026 & 31,036 & 77 & 79 & 58 \\
\hline 5th Quintile & 27,263 & 47,486 & 42,658 & 64,677 & 51 & 57 & 37 \\
\hline After-Tax Income Plu & & & & & & & \\
\hline 1st Quintile & 9,492 & 6,949 & 6,949 & 7,131 & 127 & 127 & 124 \\
\hline 2nd Quintile & 12,864 & 12,127 & 12,127 & 13,477 & 106 & 106 & 95 \\
\hline 3rd Quintile & 15,579 & 18,612 & 18,526 & 22,152 & 87 & 87 & 71 \\
\hline 4th Quintile & 19,904 & 25,815 & 25,160 & 36,355 & 78 & 81 & 55 \\
\hline 5th Quintile & 27,911 & 45,365 & 41,174 & 78,134 & 62 & 69 & 32 \\
\hline
\end{tabular}

Notes: Estimates are based on a sample of 1,115 nonmarried adults ages 65 and older. The median value is measured as the mean value between the 45 th and 55 th percentiles of the distribution.

Source: Authors' estimates from the Health and Retirement Study. 
Table 12.

Per Capita Household Expenditures and Percent in Need, by Marital Status and Spending Category

\begin{tabular}{|c|c|c|c|c|c|c|c|c|c|}
\hline & \multicolumn{3}{|c|}{ Married } & \multicolumn{3}{|c|}{ Nonmarried } & \multicolumn{3}{|c|}{ All } \\
\hline & Basic & +Transport & +Entertain & Basic & +Transport & +Entertain & Basic & +Transport & +Entertain \\
\hline \multicolumn{10}{|c|}{ A. Median Per Capita Expenditures } \\
\hline \multicolumn{10}{|l|}{ Spending Category } \\
\hline Housing & $\$ 3,823$ & $\$ 3,823$ & $\$ 3,823$ & $\$ 5,311$ & $\$ 5,311$ & $\$ 5,311$ & $\$ 4,070$ & $\$ 4,070$ & $\$ 4,070$ \\
\hline Health Care & 1,850 & 1,850 & 1,850 & 1,799 & 1,799 & 1,799 & 1,840 & 1,840 & 1,840 \\
\hline Food & 1,560 & 1,560 & 1,560 & 1,560 & 1,560 & 1,560 & 1,560 & 1,560 & 1,560 \\
\hline Clothing & 250 & 250 & 250 & 200 & 200 & 200 & 240 & 240 & 240 \\
\hline Transportation & & 1,250 & 1,250 & & 1,133 & 1,133 & & 1,239 & 1,239 \\
\hline Entertainment & & & $\underline{1,100}$ & & & 700 & & & $\underline{1,010}$ \\
\hline Sum of Components & $\$ 7,483$ & $\$ 8,733$ & $\overline{\$ 9,833}$ & $\$ 8,870$ & $\$ 10,003$ & $\$ 1 \overline{0,703}$ & $\$ 7,710$ & $\$ 8,949$ & $\overline{\$ 9,959}$ \\
\hline \multicolumn{10}{|l|}{ B. Percent Poor or In Need } \\
\hline $\begin{array}{l}\text { Poor } \\
\text { In Need }\end{array}$ & $3 \%$ & $3 \%$ & $3 \%$ & $18 \%$ & $18 \%$ & $18 \%$ & $7 \%$ & $7 \%$ & $7 \%$ \\
\hline Before-Tax Income & $8 \%$ & $12 \%$ & $16 \%$ & $19 \%$ & $24 \%$ & $27 \%$ & $10 \%$ & $14 \%$ & $18 \%$ \\
\hline After-Tax Income & $8 \%$ & $12 \%$ & $16 \%$ & $19 \%$ & $24 \%$ & $27 \%$ & $10 \%$ & $14 \%$ & $18 \%$ \\
\hline After-Tax Income Plus Assets & $6 \%$ & $8 \%$ & $10 \%$ & $16 \%$ & $19 \%$ & $21 \%$ & $8 \%$ & $10 \%$ & $13 \%$ \\
\hline
\end{tabular}

Notes: Estimates are based on a sample of 1,894 married adults and 1,115 nonmarried adults ages 65 and older. The basic needs threshold includes expenditures on housing, health care, food, and clothing. The median value is measured the 50 th percentile of the distribution.

Source: Authors' estimates from the Health and Retirement Study. 
Table 13.

Share of Adults Ages 65+ In Need, by Marital Status, Needs Threshold, and Personal Characteristics, 2001

\begin{tabular}{|c|c|c|c|c|c|c|c|c|c|}
\hline & \multicolumn{3}{|c|}{ Married } & \multicolumn{3}{|c|}{ Nonmarried } & \multicolumn{3}{|c|}{ Total } \\
\hline & $\begin{array}{c}\text { Basic } \\
(\%)\end{array}$ & $\begin{array}{c}\text { +Transport } \\
(\%) \\
\end{array}$ & $\begin{array}{c}\text { +Entertain } \\
(\%)\end{array}$ & $\begin{array}{c}\text { Basic } \\
(\%)\end{array}$ & $\begin{array}{c}\text { +Transport } \\
(\%)\end{array}$ & $\begin{array}{c}\text { +Entertain } \\
(\%)\end{array}$ & $\begin{array}{c}\text { Basic } \\
(\%)\end{array}$ & $\begin{array}{c}\text { +Transport } \\
(\%)\end{array}$ & $\begin{array}{c}\text { +Entertain } \\
(\%)\end{array}$ \\
\hline \multicolumn{10}{|c|}{ Satisfied With Retirement? } \\
\hline Very Satisfied & 5 & 7 & 10 & 12 & 15 & 16 & 6 & 8 & 11 \\
\hline Satisfied & 16 & 22 & 29 & 25 & 34 & 37 & 17 & 24 & 32 \\
\hline Not Satisfied & 30 & 40 & 45 & 28 & 38 & 38 & 29 & 38 & 43 \\
\hline \multicolumn{10}{|c|}{ Enough Monev for Food? } \\
\hline Yes & 8 & 11 & 15 & 18 & 23 & 26 & 10 & 13 & 18 \\
\hline No & 20 & 35 & 44 & 46 & 46 & 55 & 27 & 39 & 45 \\
\hline \multicolumn{10}{|c|}{ Spend or Save Extra Income? } \\
\hline Save All/Most & 4 & 5 & 9 & 10 & 13 & 15 & 5 & 7 & 10 \\
\hline Spend All/Most & 7 & 11 & 17 & 17 & 22 & 27 & 9 & 13 & 18 \\
\hline Uncertain & 13 & 18 & 24 & 23 & 28 & 31 & 15 & 19 & 25 \\
\hline
\end{tabular}

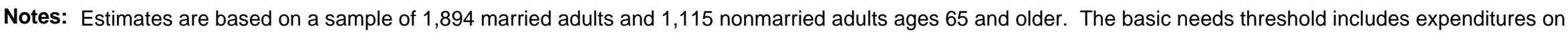
housing, health care, food, and clothing. The share in need is based on after-tax income.

Source: Authors' estimates from the Health and Retirement Study. 


\section{RECENT WORKING PAPERS FROM THE \\ CENTER FOR RETIREMENT ResearCH AT Boston College}

Understanding Expenditure Patterns in Retirement

Barbara A. Butrica, Joshua H. Goldwyn, and Richard W. Johnson, January 2005

Changes in the Distribution of Long-Run Earnings and Retirement Incomes-Have Recent Cohorts Fallen Behind?

Peter Gottschalk and Minh Huynh, January 2005

The Age Profile of Income and the Burden of Unfunded Transfers in Four Countries: Evidence from the Luxembourg Income Study

Gary Burtless, December 2004

Projecting Immigration: A Survey of the Current State of Practice and Theory Neil Howe and Richard Jackson, December 2004

Nonearnings Income Migration in the United States: Anticipating the Geographical Impacts of Baby Boom Retirement

Peter B. Nelson, December 2004

Does Work Pay at Older Ages?

Barbara A. Butrica, Richard W. Johnson, Karen E. Smith, and Eugene Steuerle, November 2004

Poverty and Income Maintenance in Old Age: A Cross-National View of Low Income Older Women

Timothy M. Smeeding and Susanna Sandstrom, November 2004

How Does Marriage Affect the Allocation of Assets in Women's Defined Contribution Plans?

Angela C. Lyons and Tansel Yilmazer, November 2004

Why Don't Americans Save?

Barry Bosworth, November 2004

How Do Pensions Affect Expected and Actual Retirement Ages?

Alicia H. Munnell, Robert K. Triest, and Natalia A. Jivan, November 2004

All working papers are available on the Center for Retirement Research website (http://www.bc.edu/crr) and can be requested by e-mail (crr@bc.edu) or phone (617-552-1762). 